\title{
Surface modifications of silica nanoparticles are crucial for their inert versus proinflammatory and immunomodulatory properties
}

This article was published in the following Dove Press journal:

International Journal of Nanomedicine

5 June 2014

Number of times this article has been viewed

\author{
Viviana Marzaioli' \\ Juan Antonio Aguilar-Pimentel ${ }^{2}$ \\ Ingrid Weichenmeier' \\ Georg Luxenhofer ${ }^{3}$ \\ Martin Wiemann ${ }^{4}$ \\ Robert Landsiedel ${ }^{5}$ \\ Wendel Wohlleben ${ }^{5}$ \\ Stefanie Eiden ${ }^{6}$ \\ Martin $\mathrm{Mempel}^{7}$ \\ Heidrun Behrendt ${ }^{1}$ \\ Carsten Schmidt-Weber' \\ Jan Gutermuth ${ }^{1,8}$ \\ Francesca Alessandrini ${ }^{1}$ \\ 'Center of Allergy and Environment \\ (ZAUM), Technische Universität and \\ Helmholtz Zentrum München, Member \\ of the German Center for Lung Research \\ (DZL), Munich, Germany; ${ }^{2}$ Department \\ of Dermatology and Allergy Biederstein, \\ Technische Universität München (TUM) and \\ German Mouse Clinic, Helmholtz Zentrum \\ München, German Research Center for \\ Environmental Health, Munich-Neuherberg, \\ Germany, ${ }^{3}$ Institute of Developmental \\ Genetics, Helmholtz Zentrum München, \\ Neuherberg, Germany; ${ }^{4}$ IBE R\&D gGmbH, \\ Münster, Germany; ${ }^{5}$ BASF, Ludwigshafen, \\ Germany; ${ }^{6}$ Bayer Technology Services, \\ Leverkusen, Germany; 'Department of \\ Dermatology, Venereology and Allergology, \\ Universitätsmedizin Göttingen (UMG), \\ Göttingen, Germany; ${ }^{8}$ Department of \\ Dermatology, Vrije Universiteit Brussel, \\ Brussels, Belgium
}

Correspondence: Francesca Alessandrini Institute for Allergy Research (IAF), Helmholtz Zentrum München/ZAUM Center of Allergy and Environment, TU München, Ingolstädter Landstr I, D-85764 Neuherberg, Germany

Tel +498931872524

Fax +498931872540

Email franci@helmholtz-muenchen.de
Background: Silica $\left(\mathrm{SiO}_{2}\right)$ nanoparticles (NPs) are widely used in diverse industrial and biomedical applications. Their applicability depends on surface modifications, which can limit potential health problems.

Objective: To assess the potential impact of $\mathrm{SiO}_{2} \mathrm{NP}$ exposure and NPs chemical modifications in allergic airway inflammation.

Methods: Mice were sensitized by five repetitive intraperitoneal injections of ovalbumin/ aluminum hydroxide $(1 \mu \mathrm{g})$ over 42 days, then intratracheally instilled with plain or modified $\mathrm{SiO}_{2}$ NPs ( $50 \mu \mathrm{g} /$ mouse), and subsequently aerosol challenged for 20 minutes with ovalbumin. One or 5 days later, allergic inflammation was evaluated by cell differentiation of bronchoalveolar lavage fluid, lung function and gene expression and histopathology, as well as electron and confocal microscopy of pulmonary tissue.

Results: Plain $\mathrm{SiO}_{2}$ NPs induced proinflammatory and immunomodulatory effects in vivo, highlighted by enhanced infiltration of inflammatory cells in the bronchoalveolar lavage fluid, induction of a pulmonary $\mathrm{T}$ helper type 2 (Th2) cytokine pattern, differentiation of type 2 macrophages, and by morphological changes in the lung of sensitized mice. These effects were dramatically attenuated using surface-functionalized NPs with amino and phosphate groups, but not with polyethylene glycol. The role of macrophages in taking up $\mathrm{SiO}_{2} \mathrm{NPs}$ was confirmed by flow cytometry, confocal microscopy, and gene expression analysis.

Conclusion: Our data suggest that amino and phosphate surface modifications, but not polyethylene glycol (PEG), mitigate the proinflammatory and immunomodulatory effect of $\mathrm{SiO}_{2}$ NPs in allergic airway inflammation, paving the way for new strategies in the production of nanomaterials with lower health impact for humans.

Keywords: immunomodulation, allergic inflammation, health impact

\section{Introduction}

Engineered nanoparticles (NPs) are frequently used in commercial products due to their unique physical and chemical characteristics, which depend on their specific dimensions (100 $\mathrm{nm}$ or less in one or more dimension). ${ }^{1}$ Silicon dioxide (silica $\left[\mathrm{SiO}_{2}\right]$ ) nanomaterials are of great importance in the fabrication of electric and thermal insulators, catalyst supports, and drug carriers, as well as in gene delivery, media for coating processes, and filler materials. ${ }^{2}$ They are also produced on an industrial scale as additives for cosmetics, drugs, printer toners, varnishes, and food packing. ${ }^{3}$ The same properties that mediate the advantages of nanotechnology also confer their potential toxic effects, resulting in a major health concern regarding the use of nanomaterials. ${ }^{1,4}$

NPs may enter the body via different routes, such as the gastrointestinal tract, ${ }^{5}$ skin, ${ }^{6,7}$ and lung. ${ }^{8,9}$ Due to their small size, NPs can translocate from entry portals into 
the circulatory and lymphatic systems, causing long-lasting cell damage. ${ }^{10,11}$ Several studies show that $\mathrm{SiO}_{2}$ NPs induce dose-dependent cytotoxicity in in vitro systems, including human lung epithelial cells ${ }^{12}$ and bronchoalveolar carcinoma-derived cells ${ }^{13}$ and human alveolar barrier, ${ }^{14}$ as well as murine macrophages. ${ }^{15}$ Short-term instillations or inhalation exposure to amorphous $\mathrm{SiO}_{2}$ NPs showed that these particles possess the potential to cause toxic effects in the lung. ${ }^{16-18}$ Immunomodulatory effects by particle exposure during the sensitization phase have also been demonstrated. ${ }^{19,20}$ Recently, surface modifications of $\mathrm{SiO}_{2}$ NPs were synthesized to study their influence on the biological activity of $\mathrm{SiO}_{2}$ NPs. In vitro studies using various mammalian cells have demonstrated that unmodified $\mathrm{SiO}_{2}$ NPs exhibit higher cytotoxic and genotoxic properties compared to surfacemodified NPs. ${ }^{18,21,22}$

The aim of this study was to investigate the effects of amorphous $\mathrm{SiO}_{2}$ NPs and their surface modifications in the elicitation phase in a murine model of ovalbumin-specific allergic airway inflammation. $\mathrm{SiO}_{2}$ and polyethylene glycol (PEG) $\mathrm{SiO}_{2}\left(\mathrm{SiO}_{2}\right.$-PEG) exerted proinflammatory and immunomodulatory activity in allergic airway inflammation, while modifying $\mathrm{SiO}_{2}$ NPs with amino and phosphate groups markedly decreased these effects. Alternative activation of pulmonary macrophages that take up $\mathrm{SiO}_{2}$ NPs and distinct chemokine patterns in the lung were identified as underlying mechanisms.

\section{Materials and methods}

\section{Animals}

Female 6- to 10-week-old BALB/c mice were obtained from Charles River (Wilmington, MA, USA), housed under specific pathogen-free conditions in individually ventilated cages (VentiRack; BioZoneGlobal Ltd, Ramsgate, UK) and fed a standard diet and water ad libitum. The study was conducted under federal guidelines for the use and care of laboratory animals and was approved by the Government of the District of Upper Bavaria and the Animal Care and Use Committee of the Helmholtz Center Munich, Munich, Germany.

\section{NP preparation}

Plain $\mathrm{SiO}_{2}\left(\mathrm{SiO}_{2}\right)$, PEGylated $\mathrm{SiO}_{2}\left(\mathrm{SiO}_{2}-\mathrm{PEG}\right)$, phosphatecoated $\mathrm{SiO}_{2}\left(\mathrm{SiO}_{2}-\mathrm{P}\right)$, and amino-coated $\mathrm{SiO}_{2}\left(\mathrm{SiO}_{2}-\mathrm{NH}_{2}\right)$ NPs were obtained from BASF SE, Ludwigshafen, Germany, and fluorescein isothiocyanate (FITC)-conjugated $\mathrm{SiO}_{2}$ ( $\mathrm{SiO}_{2}$-FITC) NPs from Bayer Technology Services $\mathrm{GmbH}$, Leverkusen, Germany. All NPs were amorphous with a single particle/agglomerate size between 5 and $50 \mathrm{~nm}$, with the exception of $\mathrm{SiO}_{2}$-FITC (23-30 nm). NPs were freshly diluted in water (aqua ad iniectabilia; B Braun Melsungen AG, Melsungen, Germany) and buffered with phosphate-buffered saline (PBS) to physiological $\mathrm{pH}$, to the final concentration of $1 \mathrm{mg} / \mathrm{mL}$, just before intratracheal instillation. Supernatant controls (SUP) were obtained by hard sedimentation $(24,000$ rpm, 15 hours). Additional NP characteristics are disclosed in the "Supplementary materials" section.

\section{Study design}

To evaluate the immunomodulatory effect of NPs, a protocol of mild allergic inflammation in the lung was used, as previously described (Figure 1A). ${ }^{23}$ Briefly, mice were sensitized by repetitive intraperitoneal injections of $1 \mu \mathrm{g}$ ovalbumin (OVA) (grade VI; Sigma-Aldrich, St Louis, MO, USA) in PBS adsorbed to $2.5 \mathrm{mg}$ aluminum

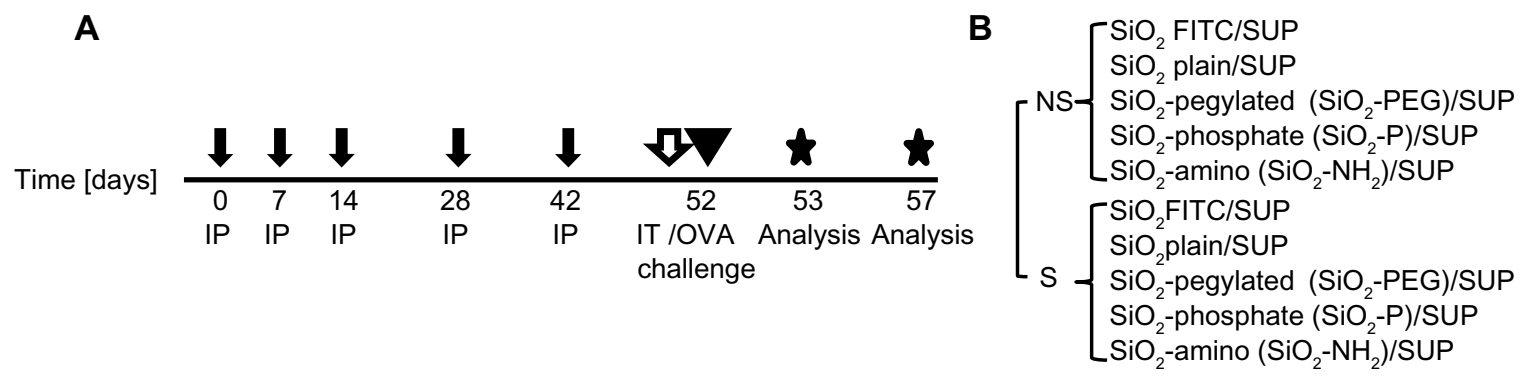

Figure I Experimental protocol.

Notes: (A) BALB/c mice were intraperitoneally sensitized (S) with OVA/aluminum hydroxide or non-sensitized (NS) with phosphate-buffered saline/aluminum hydroxide (black arrows). On day 52, S and NS mice were intratracheally instilled with $\mathrm{SiO}_{2}$ nanoparticles or with SUP (white arrow) and subsequently challenged with OVA aerosol (arrowhead). Sacrifice was on day 53 or 57, according to the analysis performed (stars). (B) Experimental groups.

Abbreviations: FITC, fluorescein isothiocyanate; IP, intraperitoneal; IT, intratracheal; OVA, ovalbumin; $\mathrm{PEG}$, polyethylene glycol; $\mathrm{SiO}_{2}$, silicon dioxide; $\mathrm{SiO}{ }_{2}-\mathrm{NH}_{2}$, aminocoated $\mathrm{SiO}_{2} ; \mathrm{SiO}_{2}-\mathrm{P}$, phosphate-coated $\mathrm{SiO}_{2} ; \mathrm{SiO}_{2}-\mathrm{PEG}$, PEGylated $\mathrm{SiO}_{2}$; SUP, supernatant controls. 
hydroxide (alum) (Thermo Fisher Scientific, Waltham, MA, USA) on days $0,7,14,28$, and 42. Blood samples were taken before and after sensitization. OVA/alum-sensitized mice (S mice), compared to non-sensitized mice (NS mice), were characterized by high titers of OVA-specific immunoglobulin $\mathrm{E}(8.05 \pm 1.64$ versus $0.1 \pm 0.03 \mu \mathrm{g} / \mathrm{mL})$. At day 52 , mice were intratracheally instilled with $50 \mu \mathrm{g}(1 \mathrm{mg} / \mathrm{mL})$ of $\mathrm{SiO}_{2}$ NPs, or with their correspondent SUP (Figure 1B). For dose-response studies, S mice were instilled with 12.5, 25 , or $50 \mu \mathrm{g}$ of $\mathrm{SiO}_{2}$ and $\mathrm{SiO}_{2}$-PEG NPs. NP instillation was followed by OVA aerosol challenge for 20 minutes with $1 \%$ OVA in PBS delivered by a PARI BOY nebulizer (PARI GmbH, Starnberg, Germany). Lung function, flow cytometry, and confocal analysis were performed on day 53. Bronchoalveolar lavage (BAL), histology, scanning electron microscopy (SEM), and messenger (m)RNA expression analysis were performed 5 days after OVA challenge (day 57).

\section{Flow cytometry}

On day 53, single cell suspensions were generated from lungs of NS and $\mathrm{S}$ mice exposed to $\mathrm{SiO}_{2}$-FITC or to corresponding SUP ( $\mathrm{n}=5-7)$, dissociated with a lung dissociation kit (kit number 130-065-927; Miltenyi Biotec GmbH, Bergisch Gladbach, Germany), and analyzed by flow cytometry, monitoring the FITC conjugate. Untreated mice were used as negative controls. To investigate the interaction of $\mathrm{SiO}_{2}$ FITC with different lung cell populations, cells were stained and gated as described previously. ${ }^{24}$ anti-mouse CD45 PECyanine7, 7AAD, and anti-mouse F4/80 PE were obtained from eBioscience (San Diego, CA, USA), anti-mouse CD11b APC-Cy ${ }^{\mathrm{TM}} 7$ from BD Biosciences (San Jose, CA, USA), anti-mouse CD11c APC from BioLegend (San Diego, CA, USA), and GR1 (LY6C/G) Pacific Orange ${ }^{\text {TM }}$ from Invitrogen (Life Technologies, Carlsbad, CA, USA). Samples were measured in a BD FACSCanto II flow cytometer and data were analyzed using a FlowJo graphics application V9.7.2 (TreeStar Inc., Ashland, OR, USA).

Interstitial macrophages were defined as $\mathrm{CD} 45^{+}, \mathrm{Gr}-1^{\text {Low }}$,

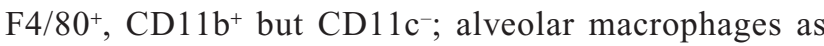
$\mathrm{CD} 45^{+}, \mathrm{Gr}-1^{\text {Low }}, \mathrm{F} 4 / 80^{+}, \mathrm{CD} 11 \mathrm{c}^{+}$but $\mathrm{CD} 11 \mathrm{~b}^{-}$; neutrophils as $\mathrm{CD}^{4} 5^{+}, \mathrm{Gr}-1^{\mathrm{High}}$, and $\mathrm{CD} 11 \mathrm{~b}^{+}$; and lymphocytes as $\mathrm{CD}^{4} 5^{+}$, but $\mathrm{CD}_{11} \mathrm{~b}^{-}$and $\mathrm{SSC}^{\mathrm{Low}}$.

\section{Confocal microscopy}

On day 53, lungs were embedded in, Tissue-Tek ${ }^{\mathrm{TM}}$ CRYOOCT Compound (Thermo Fisher Scientific), removed, and snap frozen in liquid nitrogen ( $n=2$ /group). Pulmonary tissue sections $(20 \mu \mathrm{m})$ were fixed in $4 \%$ paraformaldehyde
(Merck KGaA, Darmstadt, Germany) and subsequently blocked for 2 hours with 3\% bovine serum albumin/PBS. The primary antibody for detecting macrophages (antiCD68 marker, 1:100; AbD Serotec, Kidlington, UK) was incubated overnight and the secondary antibody ([anti-rat immunoglobulin G] Alexa Fluor ${ }^{\circledR}$ 555, 1:7000; Cell Signaling Technology, Inc., Danvers, MA USA) for 1 hour. Antibodies were diluted in $1 \%$ bovine serum albumin/PBS Nuclei were stained with 4',6-diamidino-2-phenylindole (DAPI) $(0.1 \mu \mathrm{g} / \mathrm{mL}$ in PBS; Sigma-Aldrich) for 5 minutes. Sections were embedded in Moviol 4-88 (10\% polyvinyl alcohol, 20\% glycerol in PBS; Merck). Images were acquired with an inverted confocal laser scanning microscope (LSM 510 Meta; Carl Zeiss Meditec AG, Jena, Germany) with 40× objective, Z-Stack size $6 \mu \mathrm{m}$, and collapsed two stacks. For detailed images, a 100× objective was used, with Z-Stack size $2 \mu \mathrm{m}$. Orthogonal sections of single cells were generated with the LSM Image Browser software (Carl Zeiss Meditec AG).

\section{Histology and SEM}

On day 57, after BAL, the lungs were excised and the left lobe fixed in $4 \%$ buffered formalin and embedded in paraffin ( $n=4-5 /$ group). Sections of $3 \mu \mathrm{m}$ thickness were stained with hematoxylin and eosin and periodic acid-Schiff. For electron microscopy, lungs were processed as previously described..$^{25}$

\section{Lung function analysis}

Lung function analysis was performed on day 53, 24 hours after allergen challenge in intubated, mechanically ventilated animals ( $n=5-8 /$ group; Buxco ${ }^{\circledR}$ Research Systems, Wilmington, $\mathrm{NC}, \mathrm{USA})$. Anesthesia was induced by an intraperitoneal injection of ketamine $(100 \mathrm{mg} / \mathrm{kg})$ and xylazine $(5 \mathrm{mg} / \mathrm{kg})$ in PBS. After cannulation of the trachea, the animals were ventilated with room air at rates of 130 breaths/minute. A protocol for measuring airway hyperreactivity was initiated by challenging the mice with increasing methacholine concentrations by inhalation, using an in-line nebulizer $(5 \mu \mathrm{L}$ methacholine solution in PBS delivered for 30 seconds at the following concentrations: 0 , $1.25,2.5,5,10,20$, and $40 \mathrm{mg} / \mathrm{mL}$ ). Data were recorded using FinePoint software version 1.0 (Buxco ${ }^{\circledR}$ Research Systems). The highest value of respiratory system resistance and the lowest value of dynamic compliance were recorded every 5 seconds during the data-recording interval, which was set at 3 minutes after each methacholine level. The heart rate of each animal was continuously monitored using an electrocardiography device connected with three subcutaneous electrodes throughout the entire experiment $\left(\right.$ Buxco $^{\circledR}$ Research Systems). 


\section{Polymerase chain reaction arrays and real-time polymerase chain reaction}

Total RNA was extracted from snap-frozen lung tissue as previously described. ${ }^{25}$ For polymerase chain reaction (PCR) arrays ( $\mathrm{n}=4$ /group of experiment) (SABiosciences, Hilden, Germany), $0.4 \mu \mathrm{g}$ RNA was converted into complementary (c)DNA with the RT ${ }^{2}$ First Strand Kit (Qiagen) and real-time PCR was performed with $\mathrm{RT}^{2} \mathrm{SYBR}$ Green ROX qPCR Mastermix (Qiagen) and ViiA ${ }^{\mathrm{TM}} 7$ thermocycler (Applied Biosystems; Life Technologies). Relative expression levels were calculated using the $2^{\Delta \Delta \mathrm{ct}}$ method, normalized to the arithmetic mean of glyceraldehyde-3-phosphate dehydrogenase (GAPDH) and beta-actin (ACTB). For the doseresponse experiment, $0.4 \mu \mathrm{g}$ of RNA was converted to cDNA following the manufacturer's instructions (RevertAid First Strand cDNA Synthesis Kit \#K1622; Fermentas, Thermo Fisher Scientific). Real-time PCR was performed with SYBR Green and ViiA ${ }^{\mathrm{TM}} 7$ thermocycler ( $\mathrm{n}=3 /$ group) (Applied Biosystems). Relative expression levels were calculated using the $2^{\Delta \Delta c t}$ method, normalized to ACTB. Primer sequences are listed in Table S1. Data were considered significant with a $P$-value $\leq 0.05$ with a confidence interval of $95 \%$.

\section{Data analysis}

Results are shown as boxplots indicating minimum, 25th percentile, median, 75th percentile, and maximum, or as mean \pm standard deviation. Statistical significance among groups was determined by the Mann-Whitney $U$-test for boxplots, two-way analysis of variance with post hoc least significant difference test for lung function studies, and one-way analysis of variance with Bonferroni post hoc test for PCR and flow cytometry (GraphPad Prism; GraphPad Software, Inc., La Jolla, CA, USA). Statistically significant values were categorized as follows: $P \leq 0.05, P \leq 0.01$, and $P \leq 0.001$.

\section{Results}

\section{$\mathrm{SiO}_{2} \mathrm{NPs}$ exert proinflammatory and Th2 immunomodulatory activity in vivo}

In order to investigate possible proinflammatory and immunomodulatory effects of $\mathrm{SiO}_{2}$, increasing concentrations of $\mathrm{SiO}_{2} \mathrm{NPs}(0,12.5,25$, and $50 \mu \mathrm{g} /$ mouse $)$ were intratracheally instilled in the lungs of S mice prior to OVA challenge. Bronchoalveolar lavage fluid (BALF) was analyzed for differential cell count 5 days after OVA challenge. The lowest NP concentration used $(12.5 \mu \mathrm{g})$ did not evoke a significant increase of inflammatory cells into the BALF compared to the respective SUP. Increasing NP dose to $25 \mu \mathrm{g}$ led to a significant increase of macrophages $(P<0.01)$ and neutrophils $(P<0.01)$ (Figure 2A). The highest dose of $50 \mu \mathrm{g} \mathrm{SiO}_{2}$ NPs led to a significant increase of macrophages, lymphocytes, neutrophils, and eosinophils $(P<0.001)$ in the BALF compared to sensitized SUP (Figure 2A). Similar effects were shown following $\mathrm{SiO}_{2}$-PEG instillation (Figure $\mathrm{S} 1 \mathrm{~A})$. Intratracheal instillation of $50 \mu \mathrm{g} / \mathrm{mouse} \mathrm{SiO}_{2} \mathrm{NPs}_{\text {in }}$ NS mice exerted a proinflammatory effect, leading to significantly increased neutrophils and lymphocytes $(P<0.001)$ and to a slight increase of eosinophils $(P<0.05)$ compared to non-sensitized SUP (Figure 2B). These results suggest that $\mathrm{SiO}_{2} \mathrm{NPs}$ exert both a strong proinflammatory and immunomodulatory effect in allergic airway inflammation.

\section{Pulmonary macrophages take up $\mathrm{SiO}_{2} \mathrm{NPs}$}

To determine whether OVA sensitization affects pulmonary retention of NPs, mice were instilled with $\mathrm{SiO}_{2}$-FITC or respective SUP prior to OVA challenge. Twenty-four hours later, a minor, but not significant, increase in the percentage of FITC $^{+}$cells was observed in the lung of S mice, compared to NS mice. FITC ${ }^{+}$ cells in the negative control and in S and NS mice instilled with SUP were not higher than background level (Figure 3A).

Flow cytometry of lung cell subtypes showed that macrophages displayed the highest percentage of FITC positivity. In detail, in the lungs of NS mice, $15.3 \%$ of alveolar macrophages and $8.2 \%$ of interstitial macrophages were positive for $\mathrm{SiO}_{2}$-FITC NPs. In the lungs of $\mathrm{S}$ mice, a significantly increased percentage of alveolar macrophages $(23.2 \%, P<0.01$ versus NS mice) and a reduced percentage of interstitial macrophages (4.3\%) were positive for $\mathrm{SiO}_{2}$-FITC (Figure 3A). Pulmonary suspensions of negative controls displayed minimal FITC autofluorescence, comparable to the lungs instilled with FITC-SUP. A minimal percentage of T-cells and neutrophils were FITC positive (data not shown).

To evaluate whether $\mathrm{SiO}_{2}$ NPs interacted only with the surface of macrophages or were internalized by these cells, confocal analysis was performed 24 hours after OVA challenge. Figure 3B shows representative lung sections of NS and S mice stained with the macrophage marker CD68 (red), and with DAPI for the nuclei (blue), suggesting that pulmonary macrophages take up $\mathrm{SiO}_{2} \mathrm{NPs}$ (green) in both NS and S mice. The $100 \times$ orthogonal sections of single cells show that NPs were present inside the macrophages.

\section{Specific surface modifications of $\mathrm{SiO}_{2} \mathrm{NPs}$ significantly reduce their immunomodulatory activity}

In order to evaluate the possible reduction of immunomodulatory effects on the allergic response by the 
A

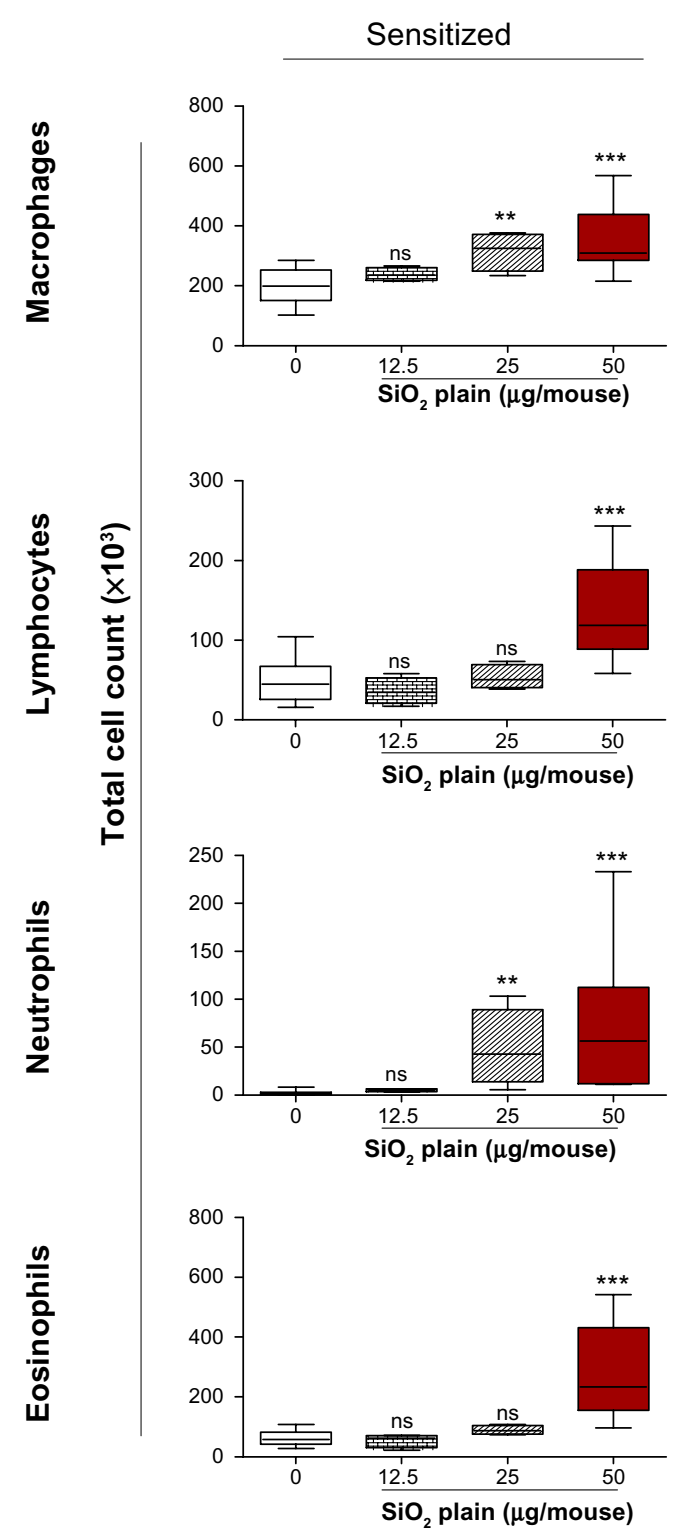

B

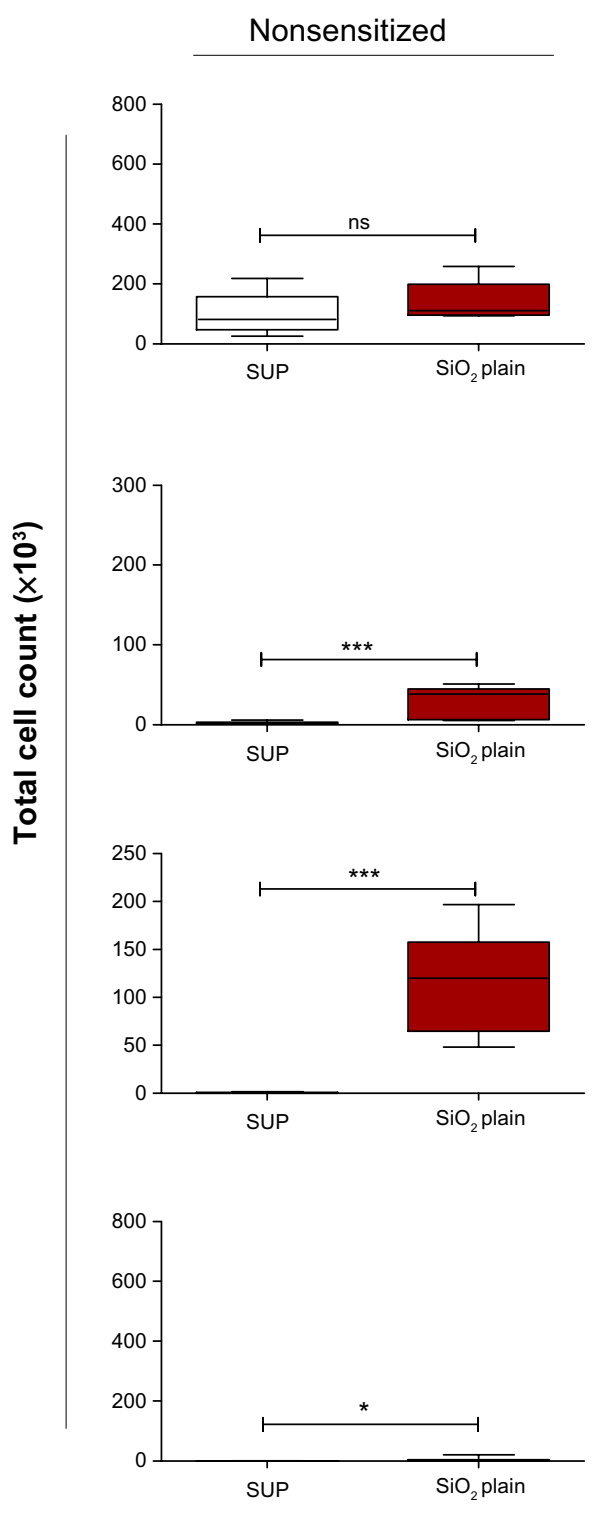

Figure $2 \mathrm{SiO}_{2} \mathrm{NPs}$ exert proinflammatory and immunomodulatory activity.

Notes: Inflammatory cell infiltration in bronchoalveolar lavage fluid of sensitized (A) and non-sensitized (B) mice 5 days after intratracheal instillation with increasing concentrations of $\mathrm{SiO}_{2} \mathrm{NPs}\left(12.5-50 \mu \mathrm{g} /\right.$ mouse, (A) or $50 \mu \mathrm{g} /$ mouse (B) SiO ${ }_{2} \mathrm{NPs}$ [pattern and red filled bar] or with respective SUP [white bars]). Data are displayed in boxplots (five to ten mice per bar). $* P \leq 0.05$; $* * P \leq 0.01$; ***P $\leq 0.001$ versus SUP $(0 \mu \mathrm{g})$.

Abbreviations: NP, nanoparticle; ns, not significant; $\mathrm{SiO}_{2}$, silicon dioxide; SUP, supernatant controls.

functionalization of $\mathrm{SiO}_{2} \mathrm{NPs}$, we evaluated the BAL cell infiltration in NS and S mice after intratracheal instillation of $\mathrm{SiO}_{2}$ NPs with PEG, amino, and phosphate surface modifications.

Similarly to $\mathrm{SiO}_{2}$ plain NPs, $\mathrm{SiO}_{2}$-PEG NPs exerted proinflammatory effects, with a significant increase of neutrophils and lymphocytes $(P<0.001)$ and a minor increase of eosinophils $(P<0.05)$, in NS mice. Moreover, functionalizing $\mathrm{SiO}_{2}$ plain NPs with PEG did not impair the immunomodulatory effect of $\mathrm{SiO}_{2} \mathrm{NPs}$ in the BALF of S mice. Lymphocyte, neutrophil, and eosinophil total cell numbers were still significantly increased in the BALF of S mice $(P<0.001)$ (Figure 4A).

In contrast, mice treated with $\mathrm{SiO}_{2}-\mathrm{P}$ or $\mathrm{SiO}_{2}-\mathrm{NH}_{2}$ (Figure 4B and $\mathrm{C}$ ) showed minimal proinflammatory effects in NS mice, which reached significance only for neutrophil and eosinophil counts in $\mathrm{SiO}_{2}-\mathrm{NH}_{2}$-treated mice $(P<0.05)$. In $\mathrm{S}$ mice, no significant effects on the BALF total cell count were shown compared to control, apart from a slight increase in the macrophage cell number after $\mathrm{SiO}_{2}-\mathrm{NH}_{2}$ instillation $(P<0.05)$. 
A

FITC $^{+}$cells

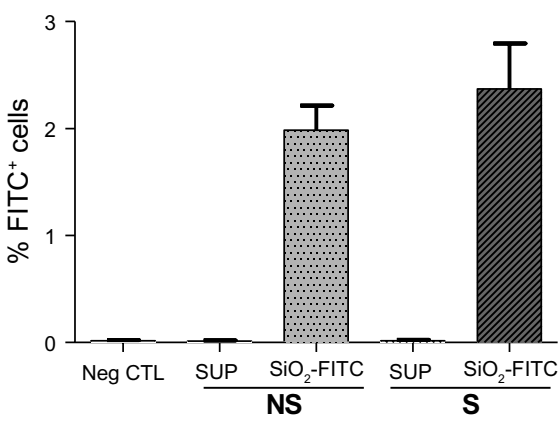

b

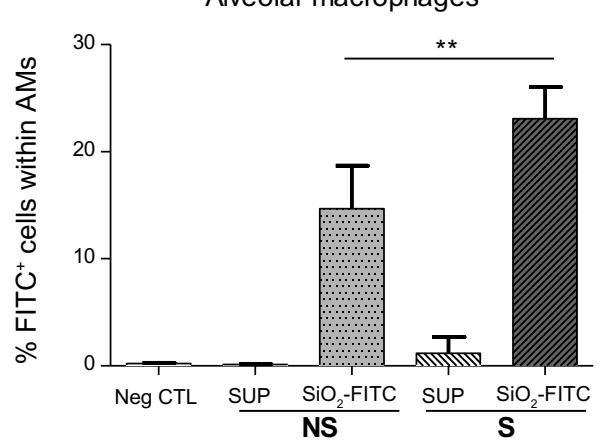

B a

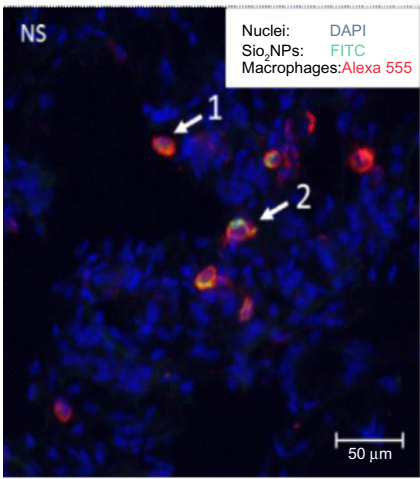

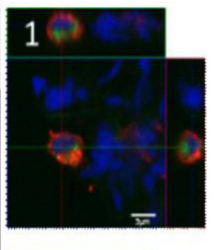

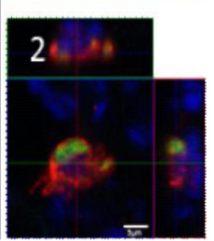

c

Interstitial macrophages

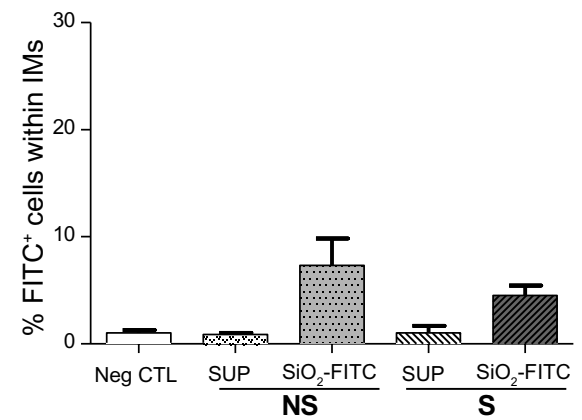

b

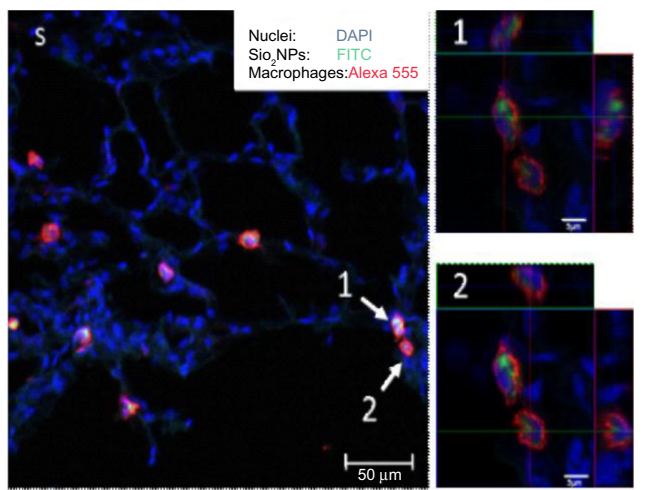

Figure 3 Macrophage populations take up nanoparticles.

Notes: (A) Percentage of FITC cells in lung (a) and within AMs (b) and IMs (c) of NS and S mice 24 hours after $50 \mu g \mathrm{SiO}_{2}-\mathrm{FITC}^{+}$and OVA challenge. Neg CTL: untreated mouse; SUP: instillation of $\mathrm{SiO}_{2}-\mathrm{FITC}$-supernatant. Mean \pm standard deviation ( $\mathrm{n}=5-7 /$ group). ${ }^{* *} \mathrm{P} \leq 0.0 \mathrm{I}$ versus $\mathrm{SUP}$. (B) NS (a) and $\mathrm{S}$ (b) lungs 24 hours after $\mathrm{SiO}-\mathrm{FITC}$ (green) and OVA challenge. Macrophages: red; nuclei: blue. Alexa 555: Alexa Fluor ${ }^{\circledR} 55$ ( I:7000; Signaling Technology, Inc., Danvers, MA USA). Left: 40× and right: I00× orthogonal sections of single cell (arrowed cells $I$ and 2).

Abbreviations: AM, alveolar macrophage; DAPI, 4',6-diamidino-2-phenylindole; FITC, fluorescein isothiocyanate; IM, interstitial macrophage; Neg CTL, negative controls; NS, non-sensitized; OVA, ovalbumin; $\mathrm{S}$, sensitized; $\mathrm{SiO}_{2}$, silicon dioxide; SUP, supernatant controls.

\section{$\mathrm{SiO}_{2}$ and $\mathrm{SiO}_{2}$-PEG increase pulmonary inflammation and goblet cell necrosis}

To further elucidate the effects of $\mathrm{SiO}_{2} \mathrm{NPs}$ and their surface coatings, we evaluated pulmonary inflammation in the lung. Intratracheal instillation of the supernatants of all four NP preparations did not affect pulmonary histopathology (Figure 5A). In $\mathrm{S}$ mice, $\mathrm{SiO}_{2}$ and $\mathrm{SiO}_{2}$-PEG NPs increased the inflammatory lung infiltrate and, although in higher degree $\mathrm{SiO}_{2}-$
PEG, mucus hypersecretion when compared to sensitized SUP mice (Figure 5A). In contrast, mice treated with $\mathrm{SiO}_{2}-\mathrm{P}$ and $\mathrm{SiO}_{2}-\mathrm{NH}_{2} \mathrm{NPs}$ showed minimal pulmonary inflammation when compared with sensitized SUP mice; these observations were in accordance with the effects observed in the BALF differential cell count in $\mathrm{S}$ mice. Irrespective of functionalization, $\mathrm{SiO}_{2} \mathrm{NPs}$ did not induce pulmonary pathological alterations in NS mice (data not shown). 
A

$\mathrm{SiO}_{2}-\mathrm{PEG}$

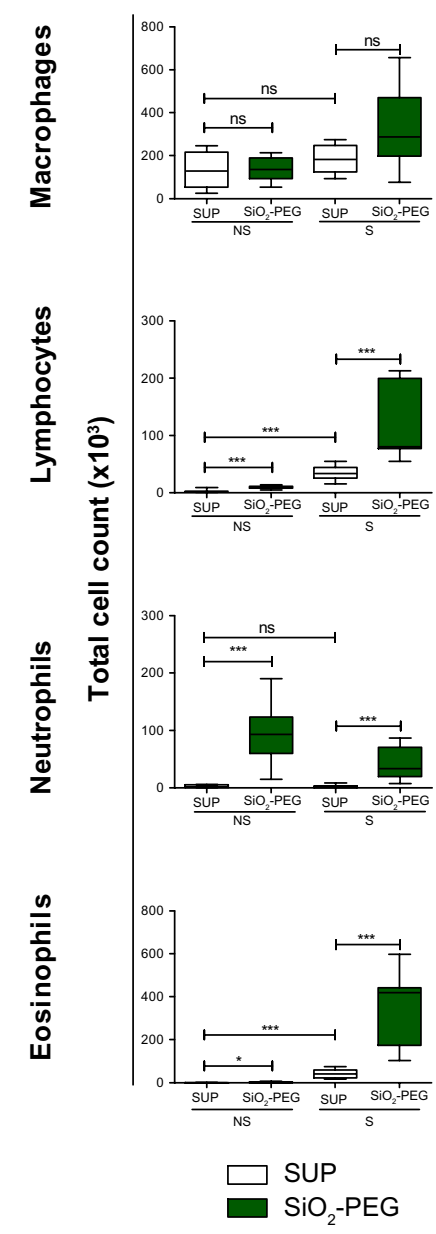

B

$\mathrm{SiO}_{2}-\mathrm{P}$
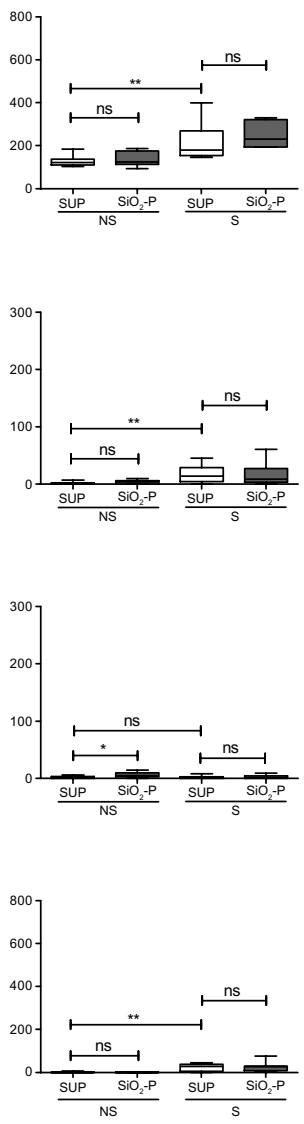

$\square$ SUP

$\square \mathrm{SiO}_{2}-\mathrm{P}$
C

$\mathrm{SiO}_{2}-\mathrm{NH}_{2}$
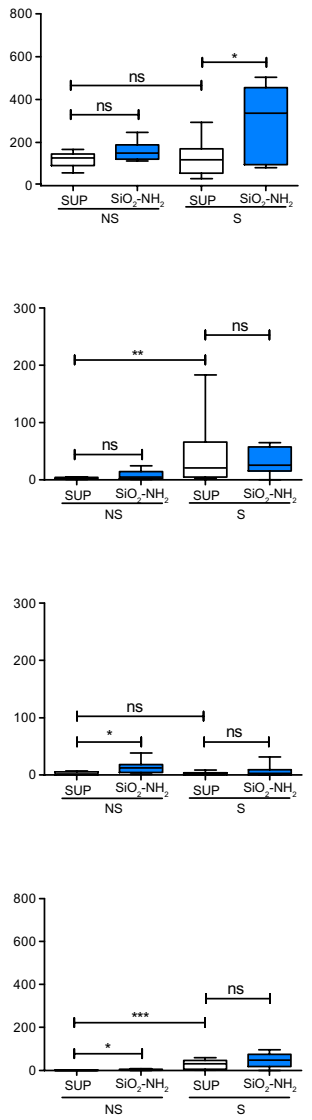

$\square \mathrm{SUP}_{\mathrm{SiO}_{2}-\mathrm{NH}_{2}}$

Figure 4 Surface modifications of $\mathrm{SiO}_{2}$ nanoparticles influence their proinflammatory and immunomodulatory effects in vivo.

Notes: Bronchoalveolar lavage fluid inflammatory infiltrate of $\mathrm{NS}$ and $\mathrm{S}$ mice 5 days after intratracheal instillation of $50 \mu_{\mathrm{g}} \mathrm{SiO}-\mathrm{PEG}(\mathbf{A}), \mathrm{SiO}_{2}-\mathrm{P}(\mathbf{B})$, or $\mathrm{SiO}-\mathrm{NH}_{2}(\mathbf{C})$, or respective SUP. Data are displayed as boxplots ( $n=6-10 /$ bar). *P $\leq 0.05 ; * * P \leq 0.01 ; * * * P \leq 0.001$.

Abbreviations: ns, not significant; NS, non-sensitized; PEG, polyethylene glycol; S, sensitized; $\mathrm{SiO}_{2}$, silicon dioxide; $\mathrm{SiO}_{2}-\mathrm{NH}_{2}$, amino-coated $\mathrm{SiO}$; $\mathrm{SiO}_{2}-\mathrm{P}$, phosphate-coated $\mathrm{SiO}_{2} ; \mathrm{SiO}_{2}-\mathrm{PEG}$, PEGylated $\mathrm{SiO}_{2}$; SUP, supernatant controls.

To evaluate structural changes of the airways following $\mathrm{SiO}_{2} \mathrm{NP}$ instillation, $\mathrm{SEM}$ was performed. NS mice instilled with the four different particles and respective supernatants showed no significant ultrastructural modifications of the lung (data not shown), apart from sporadic hypotrophy of Clara cells present in all samples (Figure 5B). S mice instilled with the four different sensitized SUP developed the classical pulmonary alterations due to OVA sensitization and challenge, ie, metaplasia of Clara cells to mucus-secreting goblet cells (Figure 5B). Lungs of $\mathrm{S}$ mice instilled with $\mathrm{SiO}_{2}$ and $\mathrm{SiO}_{2}$-PEG NPs showed morphological alterations of goblet cells, including the perforation of cell membrane, indicating cell death (Figure 5B). In contrast, no additional effects due to particle exposure were observed in $\mathrm{S}$ mice instilled with $\mathrm{SiO}_{2}-\mathrm{NH}_{2}$ or $\mathrm{SiO}_{2}-\mathrm{P}$ (Figure 5B).

\section{$\mathrm{SiO}_{2}$ and $\mathrm{SiO}_{2}-\mathrm{PEG} \mathrm{NPs}$, but not $\mathrm{SiO}_{2}-\mathrm{P}$ and $\mathrm{SiO}_{2}-\mathrm{NH}_{2} \mathrm{NPs}$, induce moderate alterations in lung function}

Lung function tests performed 24 hours after intratracheal instillation of $\mathrm{SiO}_{2} \mathrm{NPs}$ and OVA challenge in $\mathrm{S}$ mice showed different results for the four particles tested. $\mathrm{SiO}_{2}$ plain did not have an effect on respiratory system resistance when compared to SUP; however, dynamic compliance was significantly decreased in $\mathrm{S}$ mice instilled with $\mathrm{SiO}_{2}$ already, before methacholine challenge $(P<0.05)$, maintaining the lower trend at 1.25 and $2.5 \mathrm{mg} \mathrm{mL}$ 
A
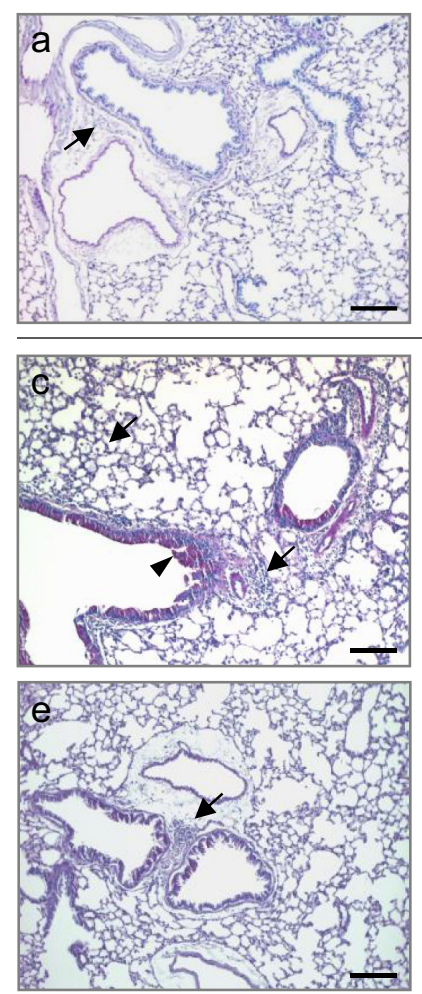
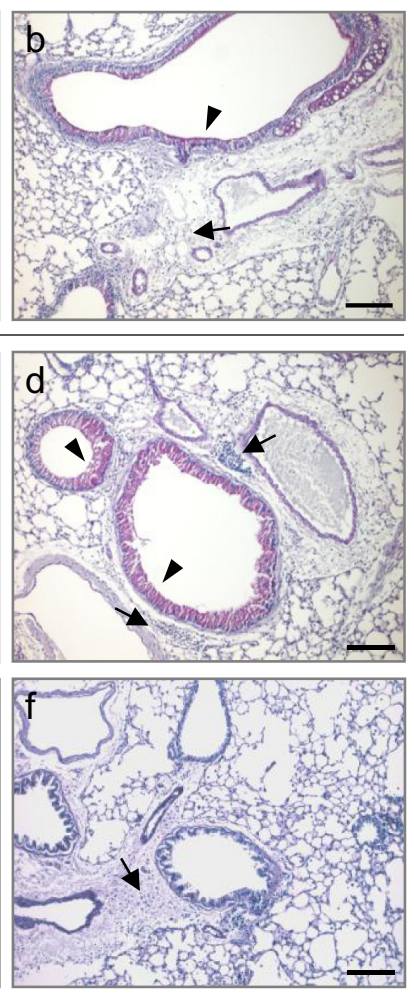

B
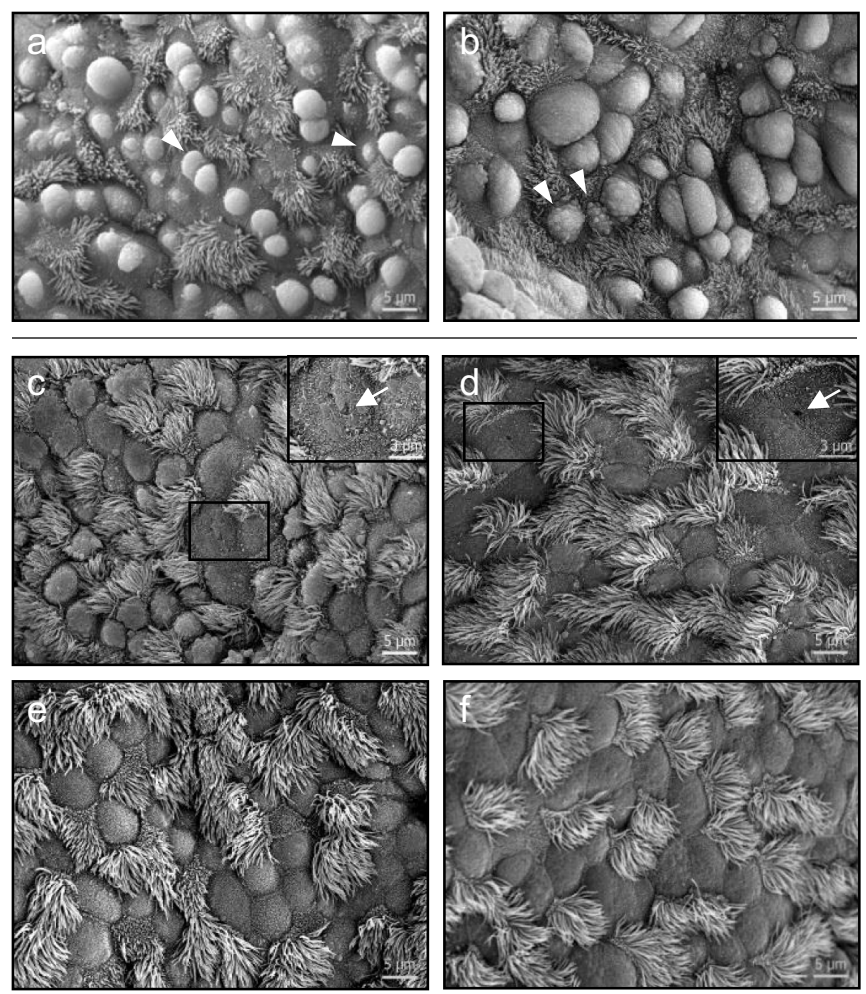

Figure $5 \mathrm{SiO}_{2}$ and $\mathrm{SiO}_{2}$-PEG NPs exacerbate goblet cell hyperplasia and induce necrosis.

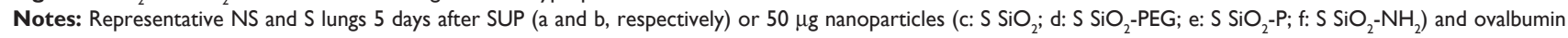
challenge. (A) Periodic acid-Schiff staining: mucus hypersecretion (arrowheads) and inflammatory infiltrate (arrows). Bar: I00 $\mu \mathrm{m}$. (B) Scanning electron microscopy of bronchiolar epithelium. (a) Clara cells (arrowheads); (b) goblet cells (arrowheads); (c and d) necrosis of goblet cells (insets, arrows). Bar: $5 \mu \mathrm{m}$ (insets: $3 \mu \mathrm{m}$ ).

Abbreviations: NS, non-sensitized; $\mathrm{PEG}$, polyethylene glycol; $\mathrm{S}$, sensitized; $\mathrm{SiO}_{2}$, silicon dioxide; $\mathrm{SiO}_{2}-\mathrm{NH}_{2}$, amino-coated $\mathrm{SiO}$; $\mathrm{SiO}_{2}-\mathrm{P}$, phosphate-coated $\mathrm{SiO}$; $\mathrm{SiO}_{2}-\mathrm{PEG}$, PEGylated $\mathrm{SiO}_{2}$; SUP, supernatant controls.

methacholine concentrations $(P=0.05$ and $P=0.06$, respectively) (Figure 6A and $\mathrm{B}$ ). The instillation of $\mathrm{SiO}_{2}-\mathrm{PEG}$ in $\mathrm{S}$ mice led to an increase of resistance following the highest methacholine concentration, namely $40 \mathrm{mg} / \mathrm{mL}(P<0.01)$. Dynamic compliance was lower in $\mathrm{SiO}_{2}-\mathrm{PEG}$ with respect to sensitized SUP, but this difference was not statistically significant (Figure 6A and $\mathrm{B}$ ). On the contrary, $\mathrm{SiO}_{2}-\mathrm{P}$ and $\mathrm{SiO}_{2}-\mathrm{NH}_{2} \mathrm{NPs}$ had no effect on either lung resistance or compliance in $\mathrm{S}$ mice (Figure $6 \mathrm{~A}$ and $\mathrm{B}$ ). The effect of the instillation of NPs in NS mice was minimal for all NPs tested (Figure 6).

\section{$\mathrm{SiO}_{2}$ and $\mathrm{SiO}_{2}-\mathrm{PEG} \mathrm{NPs}$, but not $\mathrm{SiO}_{2}-\mathrm{P}$ and $\mathrm{SiO}_{2}-\mathrm{NH}_{2} \mathrm{NPs}$, augment the Th2 proinflammatory milieu in the lungs of OVA-sensitized mice}

To characterize the distinct effects of the different surface modification of $\mathrm{SiO}_{2}$ NPs on immune responses, we performed PCR arrays on total RNA from lung homogenates.
A distinct increase of $\mathrm{T}$ helper type 2 (Th2) cytokines (interleukin [IL]-4/IL-13) was observed in S mice instilled with $\mathrm{SiO}_{2}-\mathrm{PEG}$ and, to a lesser extent, by $\mathrm{SiO}_{2}$, with no effect on Th1 (interferon- $\gamma /$ tumor necrosis factor- $\alpha$ ) cytokines (Figure 7). Different Th2 chemokines (MCP-1/ CCL2, MIP-1/CCL3, Tarc/CCL17, KC/CXCL1) involved in recruitment of macrophages, eosinophils, lymphocytes, and neutrophils were exclusively upregulated by $\mathrm{SiO}_{2}-\mathrm{PEG}$ and $\mathrm{SiO}_{2}$, and downregulated or unregulated by $\mathrm{SiO}_{2}-\mathrm{NH}_{2}$ and $\mathrm{SiO}_{2}$-P. Moreover, $\mathrm{SiO}_{2}$ and $\mathrm{SiO}_{2}$-PEG only increased markers of Th2 alternative activation of macrophage (Arg1 and Retnla) and eosinophil (Ear11) activation, and had no effect on the markers for classical activation (CXCL9, Nos2) (Figure 7 and Figure S2). These effects of NPs were observed also for other chemotactic chemokines (MIP-3/ CCL20, MDC/CCL22, MIP-2/CXCL2) as well as for asthma markers (Retnlg, Chi3l4). Muc5ac was only upregulated by $\mathrm{SiO}_{2}-\mathrm{PEG}$ in $\mathrm{S}$ mice (Figure $\mathrm{S} 2$ ). The effects of $\mathrm{SiO}_{2}$ and $\mathrm{SiO}_{2}$-PEG NP instillation on selective Th2 gene expression levels were dose dependent, and significant upregulation of 


\section{A}

Resistance

a

$\mathrm{SiO}_{2}$ plain

$\mathrm{SiO}_{2}$-PEG

$\mathrm{SiO}_{2}-\mathrm{P}$
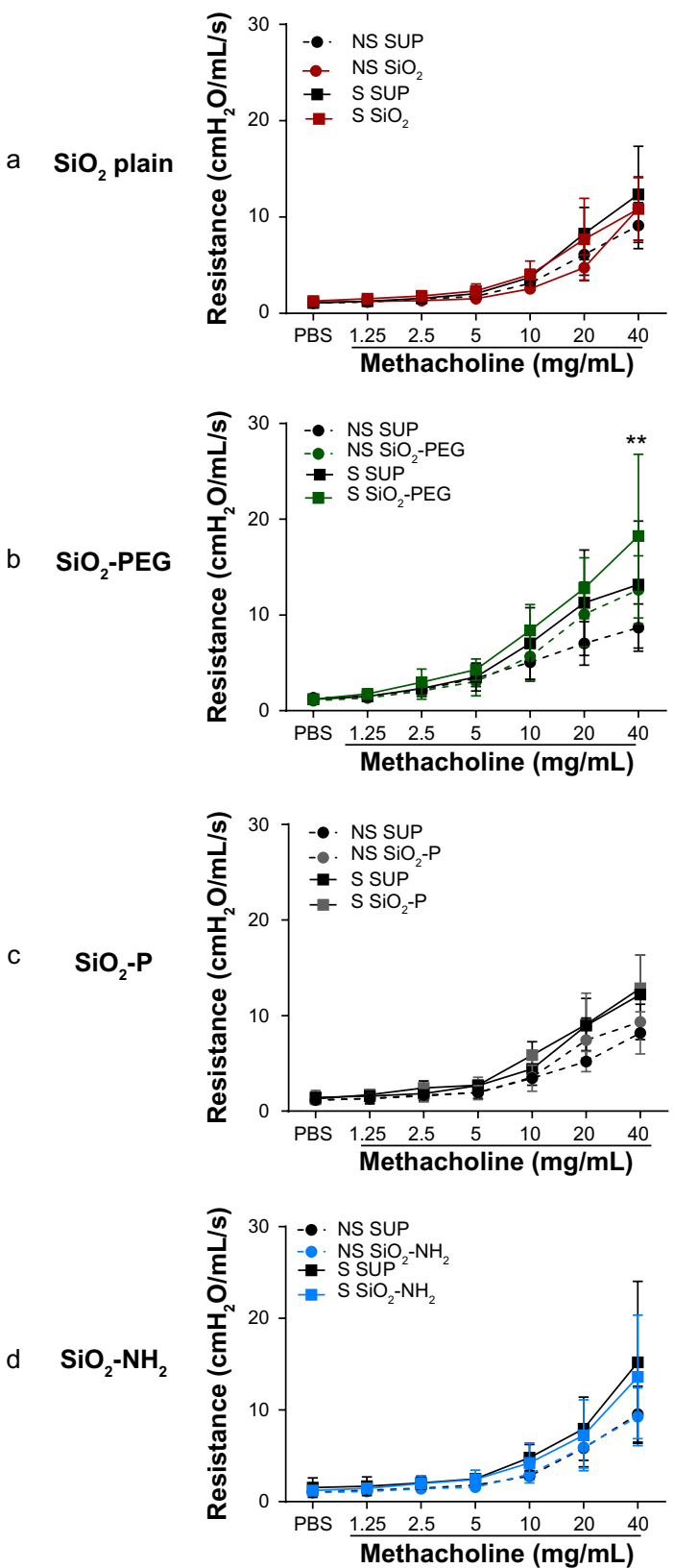

B

Compliance
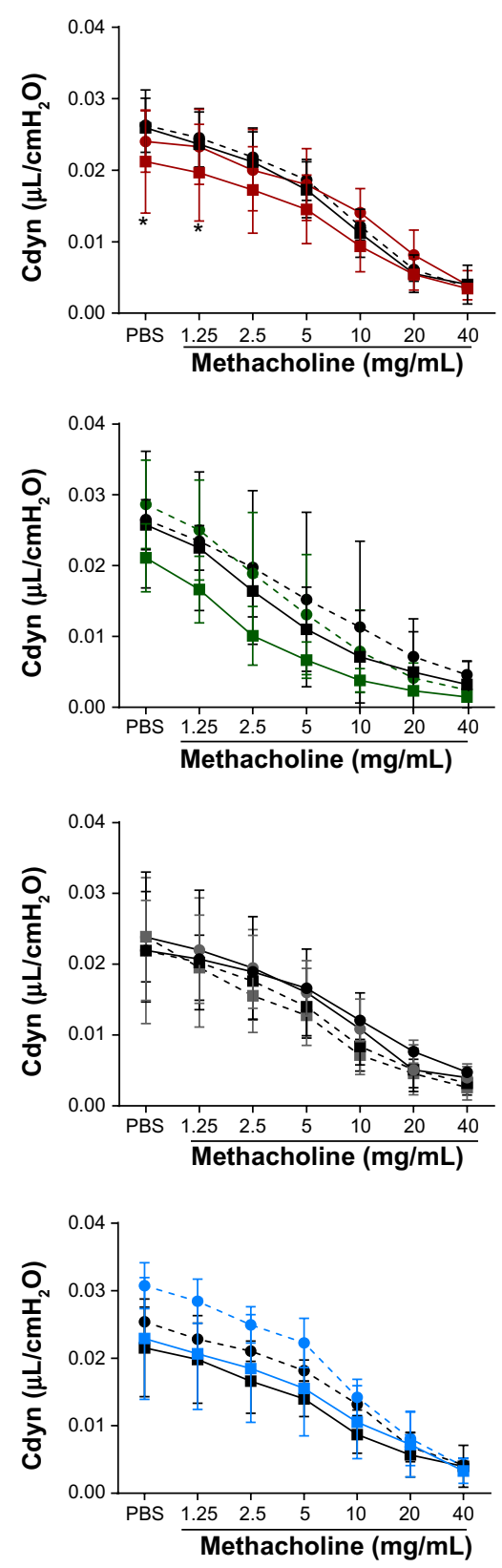

Figure $6 \mathrm{SiO}_{2}$ and $\mathrm{SiO}_{2}$-PEG nanoparticles induce moderate alterations in pulmonary function.

Notes: Lung resistance $(\mathbf{A})$ and dynamic compliance (B) of NS and S mice exposed to increasing concentrations of methacholine (I.25-40 mg/mL) 24 hours after $50 \mu \mathrm{g}$ $\mathrm{SiO}_{2}$ plain (a), $\mathrm{SiO}_{2}-\mathrm{PEG}(\mathrm{b}), \mathrm{SiO}_{2}-\mathrm{P}(\mathrm{c})$, or $\mathrm{SiO}_{2}-\mathrm{NH}_{2}$ (d) (solid lines) or respective SUP (dashed lines) and ovalbumin challenge. Mean \pm standard deviation ( $\mathrm{n}=6-8 /$ group). $* P \leq 0.05 ; * * P \leq 0.01$ versus S SUP.

Abbreviations: NS, non-sensitized; $\mathrm{PBS}$, phosphate-buffered saline; $\mathrm{PEG}$, polyethylene glycol; $\mathrm{S}$, sensitized; $\mathrm{SiO}_{2}$, silicon dioxide; $\mathrm{SiO}_{2}-\mathrm{NH}_{2}$, amino-coated $\mathrm{SiO}$; $\mathrm{SiO}_{2}-\mathrm{P}$, phosphate-coated $\mathrm{SiO}_{2} ; \mathrm{SiO}_{2}-\mathrm{PEG}, \mathrm{PEG}$ lated $\mathrm{SiO}_{2}$; SUP, supernatant controls.

IL-13, MIP-1/CCL3, and Argl was detected at the highest concentration $(50 \mu \mathrm{g} /$ mouse) (Figure S1B).

\section{Discussion}

In this study, we used a well-characterized, murine model of mild allergic airway inflammation ${ }^{23}$ to investigate $\mathrm{SiO}_{2}$
NP-mediated, surface-dependent proinflammatory and immunomodulatory effects in the lung. $\mathrm{SiO}_{2}$ plain and $\mathrm{SiO}_{2}-$ PEG exerted potent Th2-immunomodulatory activities that involved alternatively activated alveolar macrophages that presumably phagocytized $\mathrm{SiO}_{2}$ NPs. Moreover, functionalization of $\mathrm{SiO}_{2}$ NPs with amino or phosphate groups conferred 
a

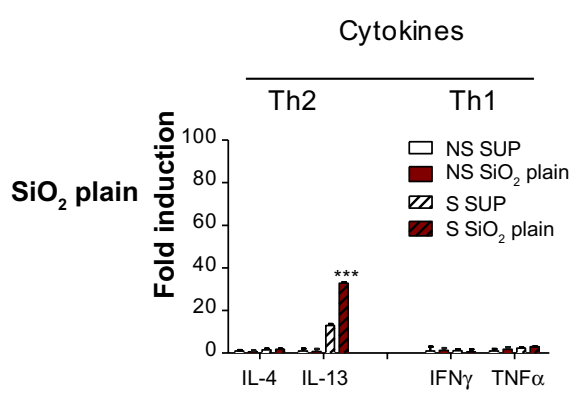

b

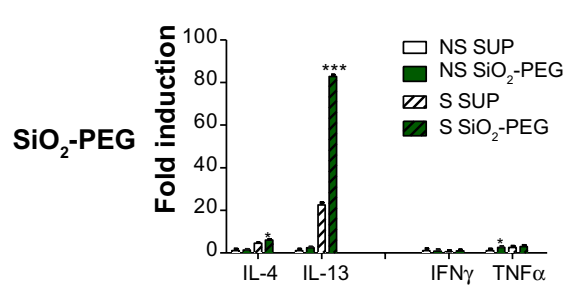

C

\section{d}
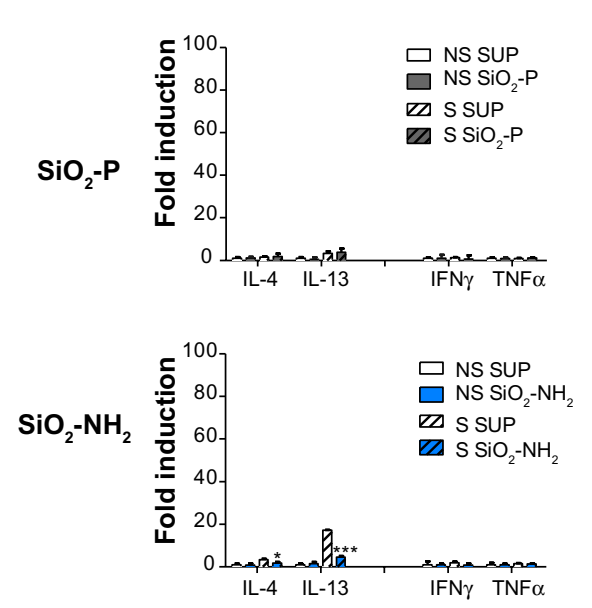

Chemokines
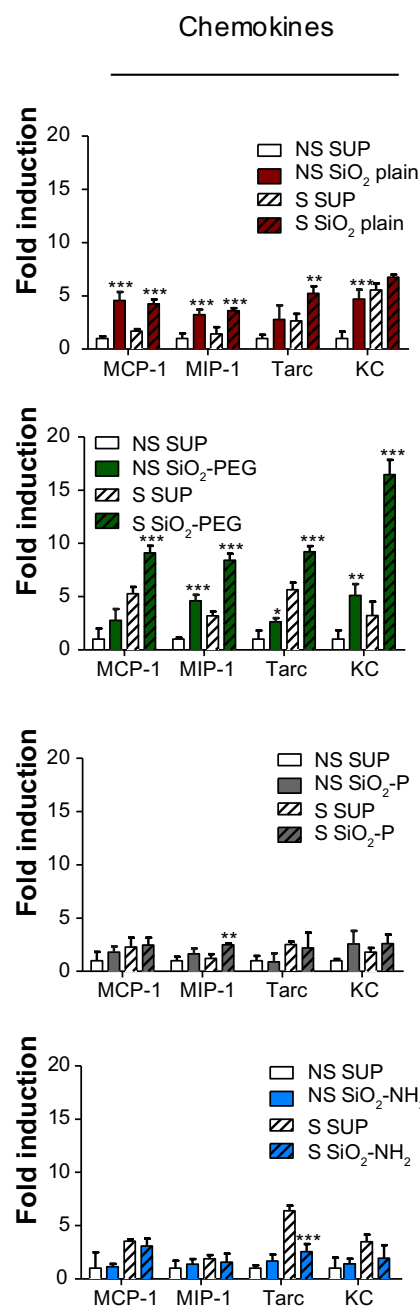
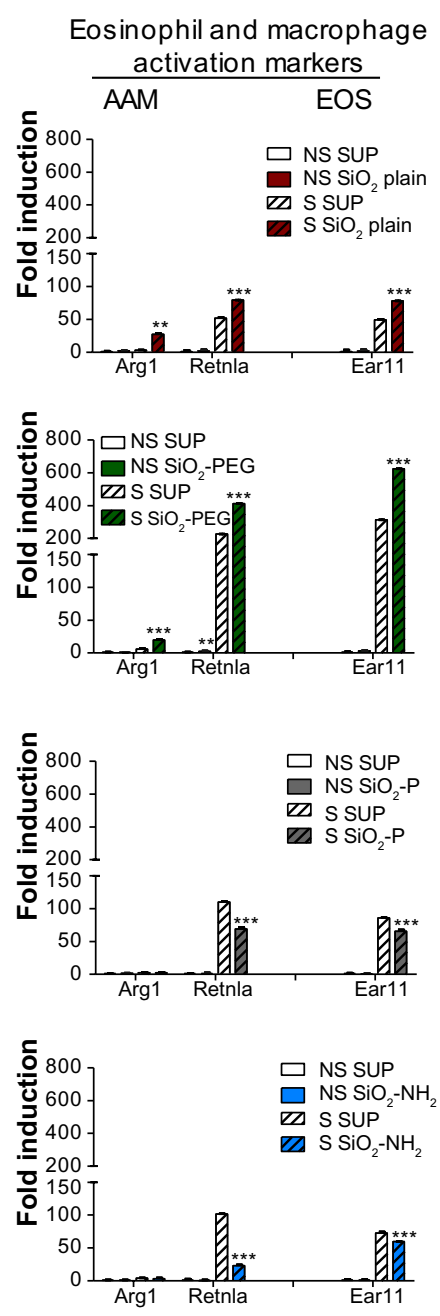

Figure $7 \mathrm{SiO}_{2}$ nanoparticles differentially modulate inflammatory genes.

Notes: Representative gene regulations in NS and $\mathrm{S}$ lungs 5 days after intratracheal instillation with $50 \mu \mathrm{g} \mathrm{SiO} \mathrm{O}_{2}$ plain (a), $\mathrm{SiO}_{2}-\mathrm{PEG}_{(\mathrm{b})}$, $\mathrm{SiO}_{2}-\mathrm{P}(\mathrm{c})$, or $\mathrm{SiO}_{2}-\mathrm{NH}_{2}$ (d), or respective SUP and ovalbumin challenge. Mean \pm standard deviation ( $n=4 /$ group). $* P \leq 0.05 ; * * P \leq 0.01 ; * * P \leq 0.001$ versus respective SUP.

Abbreviations: AAM, alternatively activated macrophages; EOS, eosinophils; IFN, interferon; IL, interleukin; NS, non-sensitized; PEG, polyethylene glycol; S, sensitized; $\mathrm{SiO}_{2}$, silicon dioxide; $\mathrm{SiO}_{2}-\mathrm{NH}_{2}$, amino-coated $\mathrm{SiO}_{2} ; \mathrm{SiO}_{2}-\mathrm{P}$, phosphate-coated $\mathrm{SiO}_{2} ; \mathrm{SiO}_{2}-\mathrm{PEG}, \mathrm{PEGylated} \mathrm{SiO}_{2} ; \mathrm{SUP}$, supernatant controls; TNF, tumor necrosis factor; ThI, Thelper type 1; Th2, Thelper type 2.

a higher NP tolerance, with a minimal inflammatory milieu in OVA-sensitized mice.

Only a few studies have investigated the modulation of allergic disease by NPs. ${ }^{19,20,26}$ Our results showed significant immunomodulatory effects exerted by $\mathrm{SiO}_{2} \mathrm{NPs}$ in OVA-sensitized mice, with a significant increase in BALF inflammatory infiltrate, mainly comprising macrophages and eosinophils. Our data are in line with a previous study testing titanium dioxide and gold NPs in the elicitation phase of the allergic response. ${ }^{26}$ We focused our read-out to day 5 after challenge. The reason for this choice was that this time point is representative for the elicitation phase of the allergic response in our mouse model, since it is characterized by strong recruitment of inflammatory cells into the lung. ${ }^{27}$ Since the Th2-adjuvant effects of $\mathrm{SiO}_{2} \mathrm{NPs}$ applied during the sensitization phase have been previously demonstrated, ${ }^{19,20}$ we now can assume that $\mathrm{SiO}_{2} \mathrm{NPs}$ also exacerbate the elicitation phase of allergic airway inflammation.

$\mathrm{SiO}_{2}$ NPs showed a strong proinflammatory effect in NS mice, leading to neutrophil and lymphocyte recruitment after intratracheal instillation, which is in agreement with a previous work ${ }^{16}$ showing neutrophil recruitment in the early inflammation stages (up to 1 week after instillation) following intratracheal instillation of $\mathrm{SiO}_{2} \mathrm{NPs}$. We also demonstrated an increase of eosinophils in NS mice exposed to $\mathrm{SiO}_{2}$ NPs, a phenomenon also observed in rats after titanium NP exposure. ${ }^{10}$

The observation that, 24 hours after intratracheal instillation, the percentage of $\mathrm{FITC}^{+}$cells in S mice was higher compared to NS mice, is in agreement with our earlier study. ${ }^{28}$ NP uptake occurred mainly by pulmonary macrophages, as has been observed in healthy animals. ${ }^{29}$ Confocal analysis 
confirmed that NPs were located inside the phagocytes, and did not just interact with the cell surface. Moreover, we demonstrated that, in $\mathrm{S}$ mice, more alveolar macrophages phagocytize NPs compared to in NS mice and, consequently, particle translocation and retention in the interstitium by interstitial macrophages occurs to a higher extent in NS mice. Since these cells exert immunoregulatory properties, this could explain the short-term NP-induced inflammation in NS mice. ${ }^{16}$ The higher percentage of phagocytizing alveolar macrophages in $\mathrm{S}$ mice relates to our observation of $\mathrm{SiO}_{2}$-dependent enhancement of expression of markers for alternatively activated macrophages, like arginase 1 and mannose receptors in NP-treated S mice. These cells show increased phagocytic activity ${ }^{30}$ and aggravate allergic airway inflammation. ${ }^{31}$ The $\mathrm{SiO}_{2}$-dependent increase in alternatively activated macrophages is of high clinical importance and could account, at least in part, for the differential localization of $\mathrm{SiO}_{2} \mathrm{NPs}$ in $\mathrm{S}$ and NS mice.

A few groups have investigated the effects of surface modifications of $\mathrm{SiO}_{2} \mathrm{NPs}$ in vitro and in vivo; ${ }^{21,22,32,33}$ however, to our knowledge, this is the first study that explores the effect of $\mathrm{SiO}_{2} \mathrm{NP}$ functionalization on their proinflammatory and immunomodulatory effects in allergic airway inflammation in vivo. Our data showed that coating NPs with short-chain PEG was not a successful strategy for modifying biological properties of $\mathrm{SiO}_{2}$ NPs: in fact, both NS and $\mathrm{S}$ mice treated with $\mathrm{SiO}_{2}$-PEG responded similarly in terms of inflammation to those treated with $\mathrm{SiO}_{2}$ plain. Moreover, both $\mathrm{SiO}_{2}$ plain and $\mathrm{SiO}_{2}-\mathrm{PEG}$ enhanced mucus production and exerted cytotoxic effects. The ultrastructural damages are very likely mediated by $\mathrm{SiO}_{2}$ NP-induced oxidative stress and apoptosis. ${ }^{34}$ Possibly, the 500 Da PEG chain used to coat the NPs was not long enough to mask the surface of the NPs. Lipka et al suggested that the PEG chain length is essential for determining the biodistribution of NPs. ${ }^{11}$ Moreover, both molecular weight and chain density of PEG influence mesoporous $\mathrm{SiO}_{2} \mathrm{NP}$ binding to serum proteins and phagocytosis from THP-1 macrophages, proposing $10 \mathrm{kDa}$ as the minimal molecular weight to inhibit phagocytosis. ${ }^{35}$ In light of these studies, our PEG chain might have been too small to mask the effect of $\mathrm{SiO}_{2} \mathrm{NPs}$. In contrast, our results showed that coating with amino or phosphate groups successfully mitigated the toxic and immunomodulatory effects of $\mathrm{SiO}_{2}$ NPs. These effects were observed at histopathological and functional levels, with less BALF cell infiltrate, absence of goblet cell necrosis, and normal lung function in both NS and $\mathrm{S}$ mice instilled with $\mathrm{SiO}_{2}-\mathrm{P}$ and $\mathrm{SiO}_{2}-\mathrm{NH}_{2}$ versus $\mathrm{SiO}_{2}$ plain or $\mathrm{SiO}_{2}$-PEG. It has been demonstrated that coating of NPs can affect their interaction with biological fluids. ${ }^{36}$ Proteins bind to the surface of NPs and form a coating known as the "protein corona," which can critically affect the interaction of the NPs with living systems. Speculation can be made as to whether our surface modifications of $\mathrm{SiO}_{2}$ NPs affected the thermodynamic characteristics of lipid monolayers, including lung surfactant or cell membrane, as previously observed in 1,2-dipalmitoyl-sn-glycerol-3-phosphocholine-cholesterol Langmuir monolayers. ${ }^{37,38}$

Different cellular uptake mechanisms may be involved when NPs are functionalized; in fact, it has been previously shown that $\mathrm{SiO}_{2}$ NPs coated with amine or carboxyl groups display a different intracellular distribution compared to those that are uncoated. ${ }^{39}$ In our model, both amino and phosphate functionalization failed to regulate markers of macrophage activation, suggesting a different compartmentalization of $\mathrm{SiO}_{2}-\mathrm{P}$ and $\mathrm{SiO}_{2}-\mathrm{NH}_{2}$ within macrophages. Further studies should investigate these aspects.

The successful mitigation of effects of $\mathrm{SiO}_{2}$ NPs coated with amino groups is in agreement with the results of Yamashita et al, ${ }^{32}$ which showed less fetotoxicity of aminocoated NPs when compared to plain NPs. To the best of our knowledge, this is the first study showing mitigation of side effects of $\mathrm{SiO}_{2}$ NPs after phosphate coating.

Our findings on the expression of key genes of inflammation support the hypothesis that functionalization of NPs modify their biological activity in vivo. The immunomodulatory NPs $\left(\mathrm{SiO}_{2}\right.$ plain and $\left.\mathrm{SiO}_{2}-\mathrm{PEG}\right)$, but not the counterpart NPs $\left(\mathrm{SiO}_{2}-\mathrm{P}\right.$ and $\left.\mathrm{SiO}_{2}-\mathrm{NH}_{2}\right)$, increased the inflammatory milieu in the pulmonary tissue, with upregulation of Th2 cytokines, as well as sensitizationinduced chemokines, the latter responsible for chemoattraction of granulocytes (MIP-1/CCL3 and MIP-2/CXCL2, KC/CXCL1), lymphocytes (Tarc/CCL17, MIP-3/CCL20, and $M D C / C C L 22)$, and macrophages (MCP-1/CCL2). ${ }^{40}$ These data support the concept of recruitment of inflammatory cells observed in the BALF of OVA-sensitized mice by immunomodulatory NPs only. Furthermore, our gene expression analysis showed that only $\mathrm{SiO}_{2}$ plain and $\mathrm{SiO}_{2}-$ PEG NPs could lead to increased marker of eosinophils activation $(\text { Ear } 11)^{41}$ and alternative activation of macrophages, with no modulation of markers of classical activation of macrophages (Arg1/Retnla versus Nos $2 / C X C L 9) .{ }^{31}$ The asthmatic profile present in the lungs of $\mathrm{S}$ mice was further confirmed by the upregulation of genes involved in allergic airway inflammation: Chitinase 3-like 4 (Chi3l4) $)^{42}$ was modulated in our experiments by both $\mathrm{SiO}_{2}$ and $\mathrm{SiO}_{2}-\mathrm{PEG}$ NPs in S mice. Among the resistin family, FIZZ1 (Retnla) and FIZZ2 (Retnlb), but not FIZZ3 (Retnlg), mRNAs were 
found to be upregulated in the lungs of S mice 6 hours after the OVA challenge: ${ }^{43}$ in this study we still found modulation of FIZZ1 and FIZZ3 in S mice 5 days after OVA challenge, which was significantly enhanced by both $\mathrm{SiO}_{2}$ and $\mathrm{SiO}_{2}-\mathrm{PEG}$ NPs and downregulated by $\mathrm{SiO}_{2}-\mathrm{NH}_{2}$. The prolongation of FIZZ1 and FIZZ3 expression after challenge may have been due to our relatively long sensitization protocol.

In most of the genes evaluated in our array, $\mathrm{SiO}_{2}-\mathrm{PEG}$ had a greater effect than $\mathrm{SiO}_{2}$. A clear example regards the regulation of the mucin $M u c 5 a c$ gene, responsible for mucus production, ${ }^{44}$ which was selectively upregulated by $\mathrm{SiO}_{2}-\mathrm{PEG}$ NPs but not by $\mathrm{SiO}_{2}$ NPs. Since $I L-13$ is a known modulator of Muc5ac, ${ }^{45}$ the lower expression of $I L-13$ mRNA upon $\mathrm{SiO}_{2}$ compared to $\mathrm{SiO}_{2}-\mathrm{PEG}$ could explain this finding.

\section{Conclusion}

Our observations indicate the need for selecting surface modifications of engineered NPs for commercial purposes, in order to improve their biological activity and reduce or abolish their side effects. Moreover, our results can inform and help in the choice of drug delivery strategy, as the selection of the surface modification of NPs is crucial for targeted application.

\section{Acknowledgments}

We thank Johanna Grosch, Benjamin Schnautz, Christine Weil, Katja Haslauer, and Alexandra Seisenberger for excellent technical assistance. We thank Claudia Traidl-Hoffmann, Tanja Seher, Antje Vennemann, and Sebastian Öder for fruitful discussions. We thank Thomas Kuhlbusch for the excellent coordination of the NanoGEM Project. This study was supported by the German Federal Ministry of Education BMBF, NanoGEM Project, FKZ 03X0105, and CK Care, Christine Kühne Center for Allergy Research and Education.

\section{Disclosure}

The authors report no conflicts of interest in this work.

\section{References}

1. Arora S, Rajwade JM, Paknikar KM. Nanotoxicology and in vitro studies: the need of the hour. Toxicol Appl Pharmacol. 2012;258:151-165.

2. Napierska D, Thomassen LC, Lison D, Martens JA, Hoet PH. The nanosilica hazard: another variable entity. Part Fibre Toxicol. 2010;7:39.

3. Hansen SF, Michelson ES, Kamper A, Borling P, Stuer-Lauridsen F, Baun A. Categorization framework to aid exposure assessment of nanomaterials in consumer products. Ecotoxicology. 2008;17:438-447.

4. Nel A, Xia T, Mädler L, Li N. Toxic potential of materials at the nanolevel. Science. 2006;311:622-627.

5. Fröhlich E, Roblegg E. Models for oral uptake of nanoparticles in consumer products. Toxicology. 2012;291:10-17.

6. Mortensen LJ, Oberdörster G, Pentland AP, Delouise LA. In vivo skin penetration of quantum dot nanoparticles in the murine model: the effect of UVR. Nano Lett. 2008;8:2779-2787.
7. Yu KO, Grabinski CM, Schrand AM, et al. Toxicity of amorphous silica nanoparticles in mouse keratinocytes. J Nanopart Res. 2009;11:15-24.

8. Kreyling WG, Semmler-Behnke M, Seitz J, et al. Size dependence of the translocation of inhaled iridium and carbon nanoparticle aggregates from the lung of rats to the blood and secondary target organs. Inhal Toxicol. 2009;21 Suppl 1:55-60.

9. Ho M, Wu KY, Chein HM, Chen LC, Cheng TJ. Pulmonary toxicity of inhaled nanoscale and fine zinc oxide particles: mass and surface area as an exposure metric. Inhal Toxicol. 2011;23: 947-956.

10. Gustafsson $\AA$, Lindstedt E, Elfsmark LS, Bucht A. Lung exposure of titanium dioxide nanoparticles induces innate immune activation and long-lasting lymphocyte response in the Dark Agouti rat. J Immunotoxicol. 2011;8:111-121.

11. Lipka J, Semmler-Behnke M, Sperling RA, et al. Biodistribution of PEG-modified gold nanoparticles following intratracheal instillation and intravenous injection. Biomaterials. 2010;31: 6574-6581.

12. Berg JM, Romoser AA, Figueroa DE, Spencer West C, Sayes CM. Comparative cytological responses of lung epithelial and pleural mesothelial cells following in vitro exposure to nanoscale $\mathrm{SiO}_{2}$. Toxicol In Vitro. 2013;27:24-33.

13. Lin W, Huang YW, Zhou XD, Ma Y. In vitro toxicity of silica nanoparticles in human lung cancer cells. Toxicol Appl Pharmacol. 2006;217:252-259.

14. Farcal LR, Uboldi C, Mehn D, et al. Mechanisms of toxicity induced by $\mathrm{SiO} 2$ nanoparticles of in vitro human alveolar barrier: effects on cytokine production, oxidative stress induction, surfactant proteins A mRNA expression and nanoparticles uptake. Nanotoxicology. 2013;7(6): 1095-1110.

15. Park MDZ, Lynch I, Ramírez-García S, et al. In vitro evaluation of cytotoxic and inflammatory properties of silica nanoparticles of different sizes in murine RAW 264.7 macrophages. J Nanopart Res. 2011;13: 6775-6787.

16. Cho WS, Choi M, Han BS, et al. Inflammatory mediators induced by intratracheal instillation of ultrafine amorphous silica particles. Toxicol Lett. 2007;175:24-33.

17. Klein CL, Wiench K, Wiemann M, Ma-Hock L, van Ravenzwaay B, Landsiedel R. Hazard identification of inhaled nanomaterials: making use of short-term inhalation studies. Arch Toxicol. 2012;86: 1137-1151.

18. Landsiedel R, Ma-Hock L, Kroll A, et al. Testing metal-oxide nanomaterials for human safety. Adv Mater. 2010;22:2601-2627.

19. Han B, Guo J, Abrahaley T, et al. Adverse effect of nano-silicon dioxide on lung function of rats with or without ovalbumin immunization. PLoS One. 2011;6:e17236.

20. Brandenberger C, Rowley NL, Jackson-Humbles DN, et al. Engineered silica nanoparticles act as adjuvants to enhance allergic airway disease in mice. Part Fibre Toxicol. 2013;10:26.

21. Lankoff A, Arabski M, Wegierek-Ciuk A, et al. Effect of surface modification of silica nanoparticles on toxicity and cellular uptake by human peripheral blood lymphocytes in vitro. Nanotoxicology. 2013;7(3): 235-250.

22. Morishige T, Yoshioka Y, Inakura $\mathrm{H}$, et al. The effect of surface modification of amorphous silica particles on NLRP3 inflammasome mediated IL-1 beta production, ROS production and endosomal rupture. Biomaterials. 2010;31:6833-6842.

23. Alessandrini F, Schulz H, Takenaka S, et al. Effects of ultrafine carbon particle inhalation on allergic inflammation of the lung. J Allergy Clin Immunol. 2006;117:824-830.

24. Bedoret $\mathrm{D}$, Wallemacq $\mathrm{H}$, Marichal $\mathrm{T}$, et al. Lung interstitial macrophages alter dendritic cell functions to prevent airway allergy in mice. J Clin Invest. 2009;119:3723-3738.

25. Alessandrini F, Weichenmeier I, van Miert E, et al. Effects of ultrafine particles-induced oxidative stress on Clara cells in allergic lung inflammation. Part Fibre Toxicol. 2010;7:11. 
26. Hussain S, Vanoirbeek JA, Luyts K, et al. Lung exposure to nanoparticles modulates an asthmatic response in a mouse model. Eur Respir J. 2011;37:299-309.

27. Alessandrini F, Beck-Speier I, Krappmann D, et al. Role of oxidative stress in ultrafine particle-induced exacerbation of allergic lung inflammation. Am J Respir Crit Care Med. 2009;179:984-991.

28. Alessandrini F, Semmler-Behnke M, Jakob T, Schulz H, Behrendt H, Kreyling W. Total and regional deposition of ultrafine particles in a mouse model of allergic inflammation of the lung. Inhal Toxicol. 2008;20:585-593.

29. Morfeld P, Treumann S, Ma-Hock L, Bruch J, Landsiedel R. Deposition behavior of inhaled nanostructured $\mathrm{TiO}_{2}$ in rats: fractions of particle diameter below $100 \mathrm{~nm}$ (nanoscale) and the slicing bias of transmission electron microscopy. Inhal Toxicol. 2012;24:939-951.

30. Alexis NE, Soukup J, Nierkens S, Becker S. Association between airway hyperreactivity and bronchial macrophage dysfunction in individuals with mild asthma. Am J Physiol Lung Cell Mol Physiol. 2001;280:L369-L375

31. Moreira AP, Hogaboam CM. Macrophages in allergic asthma: fine-tuning their pro- and anti-inflammatory actions for disease resolution. J Interferon Cytokine Res. 2011;31:485-491.

32. Yamashita K, Yoshioka Y, Higashisaka K, et al. Silica and titanium dioxide nanoparticles cause pregnancy complications in mice. Nat Nanotechnol. 2011;6:321-328.

33. Yoshida T, Yoshioka Y, Matsuyama K, et al. Surface modification of amorphous nanosilica particles suppresses nanosilica-induced cytotoxicity, ROS generation, and DNA damage in various mammalian cells. Biochem Biophys Res Commun. 2012;427:748-752.

34. Ahamed M. Silica nanoparticles-induced cytotoxicity, oxidative stress and apoptosis in cultured A431 and A549 cells. Hum Exp Toxicol. 2013;32:186-195.

35. He Q, Zhang J, Shi J, et al. The effect of PEGylation of mesoporous silica nanoparticles on nonspecific binding of serum proteins and cellular responses. Biomaterials. 2010;31:1085-1092.
36. Monopoli MP, Aberg C, Salvati A, Dawson KA. Biomolecular coronas provide the biological identity of nanosized materials. Nat Nanotechnol. 2012;7(12):779-786.

37. Guzmán E, Ferrari M, Santini E, Liggieri L, Ravera F. Influence of silica nanoparticles on phase behavior and structural properties of DPPC Palmitic acid Langmuir monolayers. Colloids Surf A Physicochem Eng Asp. 2012;413:280-287.

38. Guzmán E, Liggieri L, Santini E, Ferrari M, Ravera F. Mixed DPPCcholesterol Langmuir monolayers in presence of hydrophilic silica nanoparticles. Colloids Surf B Biointerfaces. 2013;105:284-293.

39. Nabeshi H, Yoshikawa T, Arimori A, et al. Effect of surface properties of silica nanoparticles on their cytotoxicity and cellular distribution in murine macrophages. Nanoscale Res Lett. 2011;6:93.

40. Palmqvist C, Wardlaw AJ, Bradding P. Chemokines and their receptors as potential targets for the treatment of asthma. Br J Pharmacol. 2007; 151:725-736.

41. Cormier SA, Yuan S, Crosby JR, et al. T(H)2-mediated pulmonary inflammation leads to the differential expression of ribonuclease genes by alveolar macrophages. Am J Respir Cell Mol Biol. 2002;27: 678-687.

42. Zhang Q, Hitchins VM, Schrand AM, Hussain SM, Goering PL. Uptake of gold nanoparticles in murine macrophage cells without cytotoxicity or production of pro-inflammatory mediators. Nanotoxicology. 2011;5:284-295.

43. Stütz AM, Pickart LA, Trifilieff A, Baumruker T, Prieschl-Strassmayr E, Woisetschläger M. The Th2 cell cytokines IL-4 and IL-13 regulate found in inflammatory zone $1 /$ resistin-like molecule alpha gene expression by a STAT6 and CCAAT/enhancer-binding protein-dependent mechanism. J Immunol. 2003;170:1789-1796.

44. Rose MC, Voynow JA. Respiratory tract mucin genes and mucin glycoproteins in health and disease. Physiol Rev. 2006;86:245-278.

45. Kanoh S, Tanabe T, Rubin BK. IL-13-induced MUC5AC production and goblet cell differentiation is steroid resistant in human airway cells. Clin Exp Allergy. 2011;41:1747-1756. 


\section{Supplementary materials} Nanoparticle characteristics

Covalent functionalization of nanoparticles (NPs) was obtained with three different low-molar-mass silanes:

- PEGylated silicon dioxide (silica $\left[\mathrm{SiO}_{2}\right]$ ) NPs: polyethylene glycol of chain length molecular weight $=500 \mathrm{~g} / \mathrm{mol}$.

- Amino-coated $\mathrm{SiO}_{2} \mathrm{NPs}$ : carry a positively charged amino end group on a flexible, but short C3 linker.

- Phosphate-coated $\mathrm{SiO}_{2}$ NPs: carries a negatively charged $\mathrm{PO}_{3}$ end group on the same $\mathrm{C} 3$ linker.

Successful functionalization was confirmed by transmission electron microscopy, which showed that NPs maintained a spherical structure with no aggregates, agglomerates, or secondary nucleation. Size distribution in water as measured by analytical ultracentrifugation ${ }^{1}$ was not significantly changed by the surface modification, with a peak diameter at $14 \mathrm{~nm}$ as shown in Figure S3A. Surface charge was measured by electrophoretic mobility with $\mathrm{pH}$ titration (Figure S3B), showing that the non-functionalized $\mathrm{SiO}_{2}$ NPs (plain) retained their negative charge across the physiological $\mathrm{pH}$ range; phosphate-coated $\mathrm{SiO}_{2} \mathrm{NPs}$ was strongly negatively charged; and the charge was reduced in PEGylated $\mathrm{SiO}_{2}$ and inverted to positive values in aminocoated $\mathrm{SiO}_{2}$.

Moreover, surface chemistry was evaluated by secondary ion mass spectrometry measurements, showing the presence
A

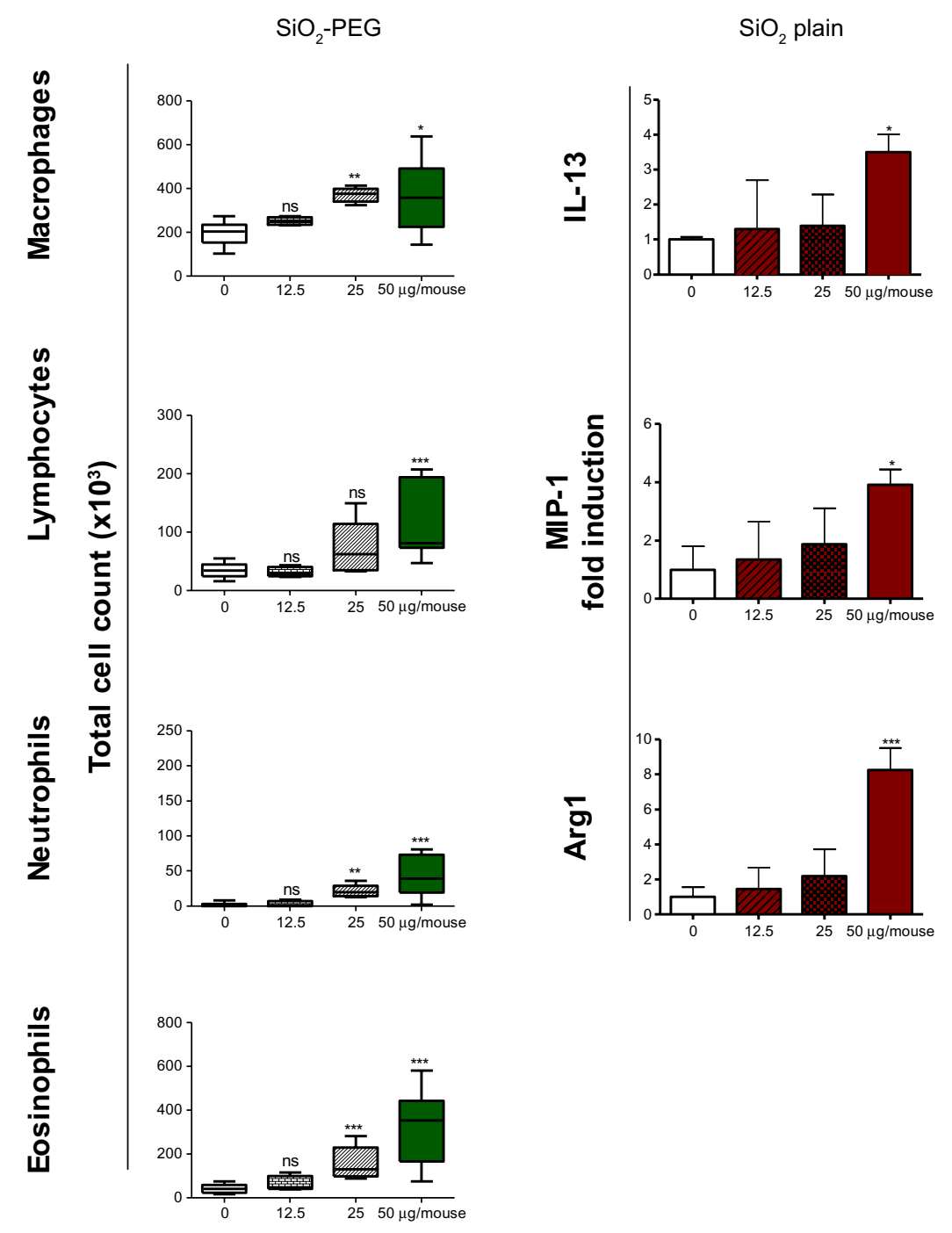

B 

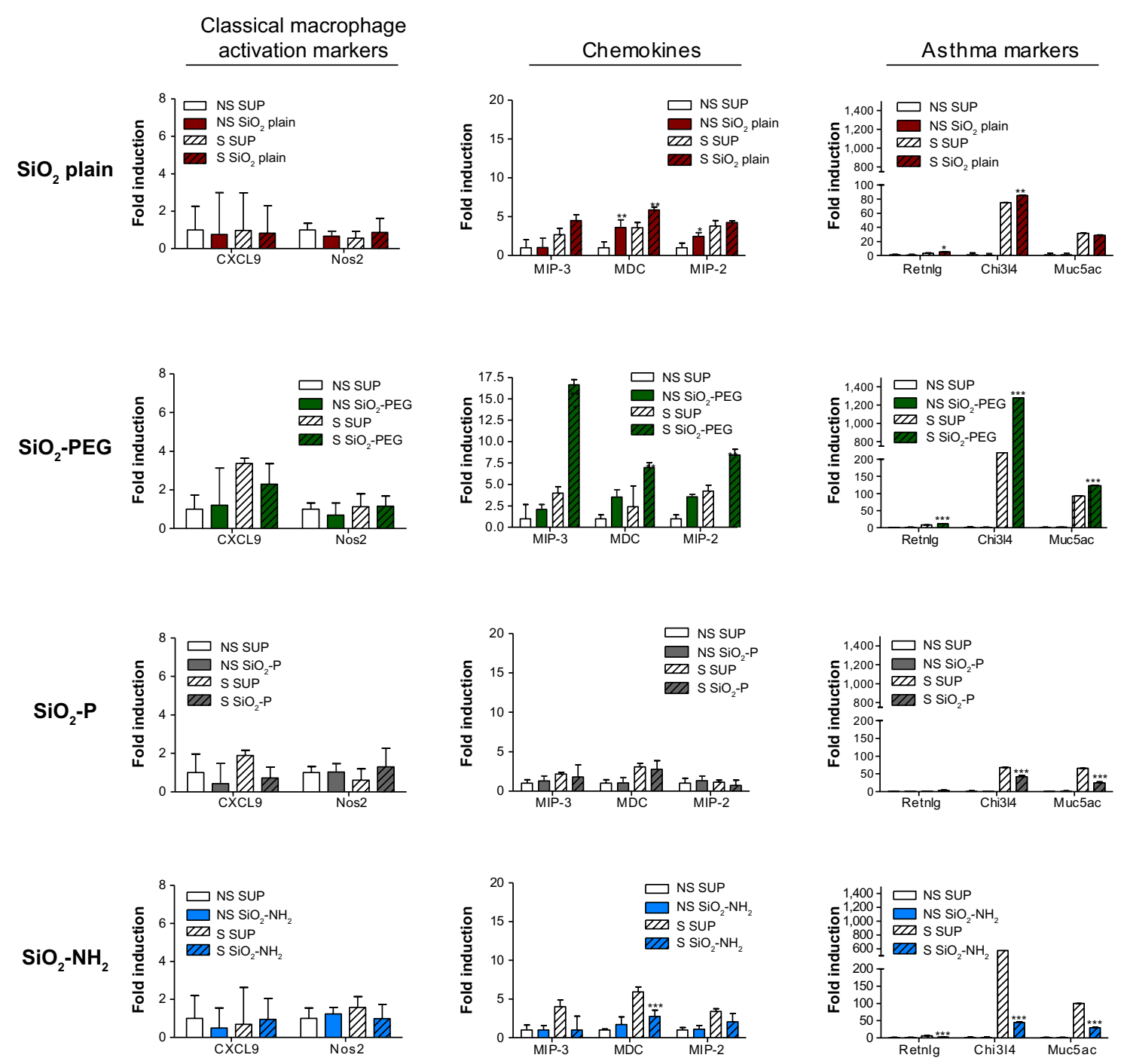

Figure $\mathbf{S 2} \mathrm{SiO}_{2}$ nanoparticles differentially modulate inflammatory genes.

Notes: Representative gene regulations in NS and $\mathrm{S}$ lungs 5 days after intratracheal instillation with $50 \mu \mathrm{g} \mathrm{SiO}{ }_{2}, \mathrm{SiO}_{2}-\mathrm{PEG}, \mathrm{SiO}_{2}-\mathrm{P}_{\text {or }} \mathrm{SiO}_{2}-\mathrm{NH}_{2}$, or respective $\mathrm{SUP}_{\text {(white) }}$ and ovalbumin challenge. Mean \pm standard deviation ( $n=4 /$ group). $* P \leq 0.05 ; * * P \leq 0.01 ; * * * P \leq 0.00$ I versus respective SUP.

Abbreviations: NS, non-sensitized; PEG, polyethylene glycol; S, sensitized; $\mathrm{SiO}_{2}$, silicon dioxide; $\mathrm{SiO}_{2}-\mathrm{NH}_{2}$, amino-coated $\mathrm{SiO}_{2}$; $\mathrm{SiO}_{2}-\mathrm{P}$, phosphate-coated $\mathrm{SiO}{ }_{2}$; $\mathrm{SiO}_{2}-\mathrm{PEG}$, PEGylated $\mathrm{SiO}_{2}$; SUP, supernatant controls.

of free $\mathrm{SiOx}$ groups and free functionalized groups, underlining a partial coverage of the NPs (Figure S3C shows an example of one of the NPs used in this study, phosphatecoated $\mathrm{SiO}_{2} \mathrm{NPs}$ ). All NPs used in this study were tested for lipopolysaccharide concentration. This was $<0.25 \mathrm{EU} /$ $\mathrm{mL}$ NPs suspension, which resulted in $<0.000055 \mathrm{EU} /$ intratracheal instillation for the highest NP concentrations as determined by limulus amebocyte lysate assay (PyroGene rFC Endotoxin Detection system, product number 50-658U; Lonza Group Ltd, Basel, Switzerland).

Supernatants for each NP were obtained by hard sedimentation (24,000 rpm, 15 hours), with successful removal

Table SI Murine primers for real-time polymerase chain reaction

\begin{tabular}{|c|c|c|c|}
\hline Gene name & GenBank accession number & Primer forward $5^{\prime}-3^{\prime}$ & Primer reverse $5^{\prime}-3^{\prime}$ \\
\hline ILI3 & NM_008355.3 & ССTCTGACCCTTAAGGAGCTTAT & CGTTGCACAGGGGAGTCT \\
\hline$M I P-I / C \mathrm{cl} 3$ & NM_0II337.2 & TTCTCTGTACCATGACACTCTGC & CGTGGAATCTTCCGGCTGTAG \\
\hline $\operatorname{Arg} 1$ & NM_007482.3 & GGAACCCAGAGAGAGCATGA & TTTTTCCAGCAGACCAGCTT \\
\hline ACTB & NM 007393.3 & TTCTTTGCAGCTCCTTCGTT & ATGGAGGGGAATACAGCCC \\
\hline
\end{tabular}

Abbreviations: ILI3, interleukin I3; MIP-I/CCL3, macrophage inflammatory protein I/Chemokine (C-C motif) ligand 3; ARGI, arginase; ACTB, actin beta. 

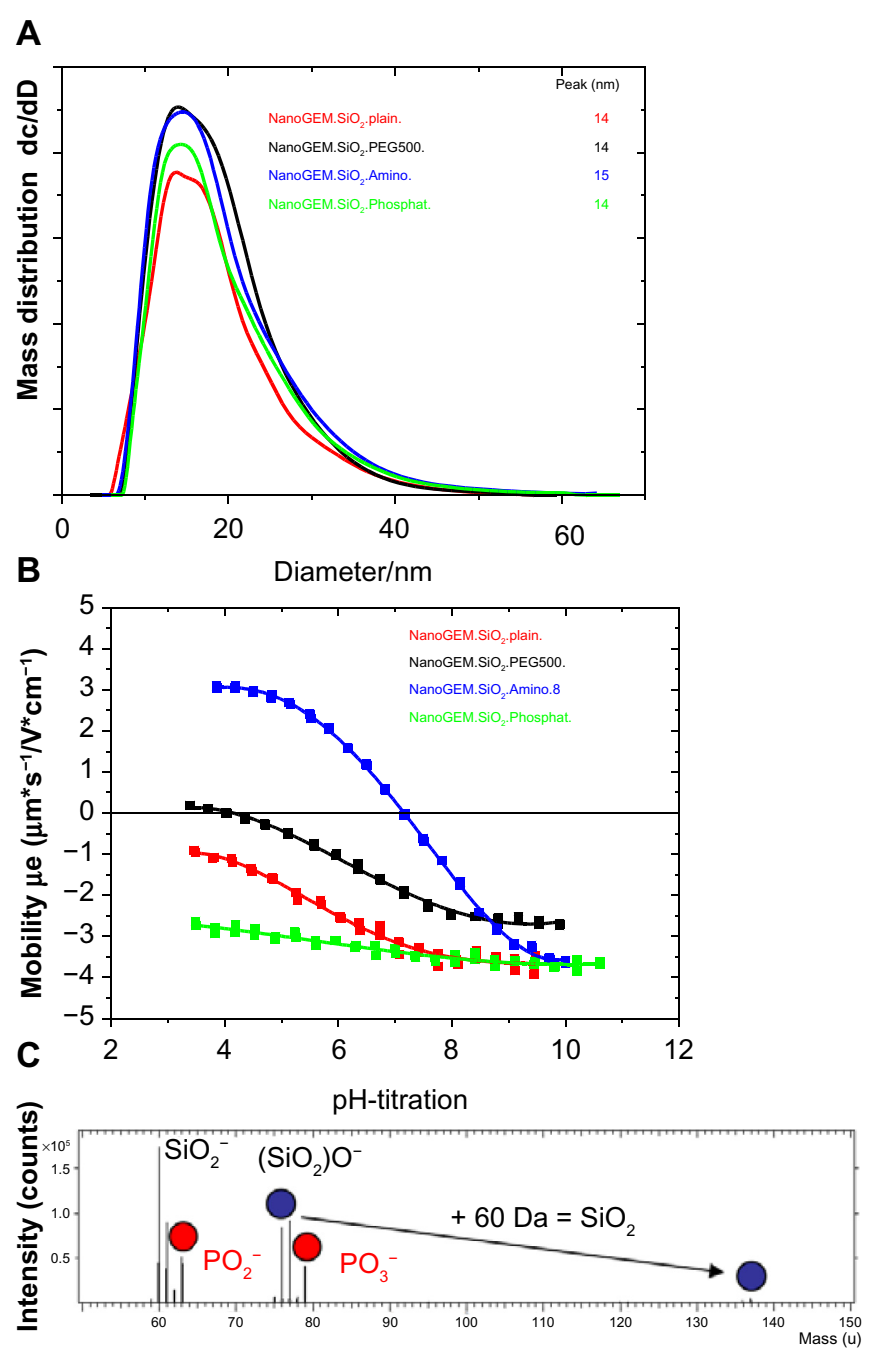

Figure S3 Physical-chemical characterization.

Notes: (A) Size distributions by analytical ultracentrifugation (AUC), plotted as differential distribution of concentration dc per diameter interval dD. The area under the curve is proportional to the mass within this diameter range; (B) Surface charge by electrophoretic mobility with $\mathrm{pH}$ titration; (C) Surface chemistry by SIMS (SiO $\left.{ }_{2}-\mathrm{P}\right)$, showing in the top $\mathrm{Inm}$ layer of the particles both the added $\mathrm{PO}_{3}$ functionality and the intrinsic $\mathrm{SiO}_{2}$ fragments of the intrinsic surface chemistry.

Abbreviations: $\mathrm{SiO}_{2}$, silicon dioxide; $\mathrm{SiO}_{2}-\mathrm{NH}_{2}$, amino-coated $\mathrm{SiO}_{2} ; \mathrm{SiO}_{2}-\mathrm{P}$, phosphate-coated $\mathrm{SiO}_{2} ; \mathrm{SiO}_{2}-\mathrm{PEG}, \mathrm{PEGylated} \mathrm{SiO}_{2} ; \mathrm{PEG}$, polyethylene glycol; dC/dD, distribution of concentration per diameter interval.

A

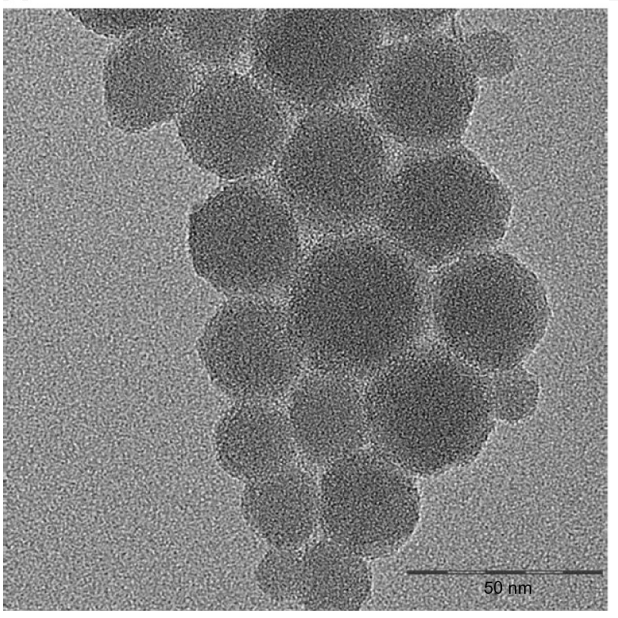

B

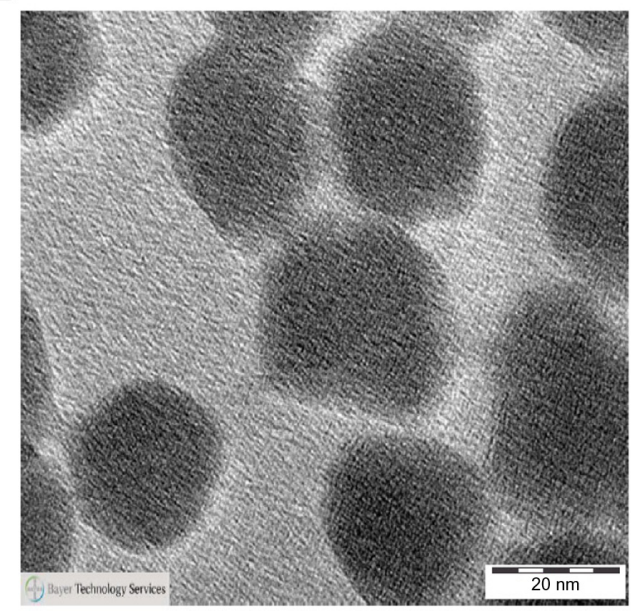

Figure $\mathrm{S} 4$ Size and agglomeration characterization of $\mathrm{SiO}_{2} \mathrm{NPs}$ by transmission electron microscopy.

Note: (A) Silicon dioxide (plain) and (B) silicon dioxide-fluorescein isothiocyanate nanoparticles.

Abbreviations: $\mathrm{SiO}_{2}$, silicon dioxide; NPs, nanoparticles. 


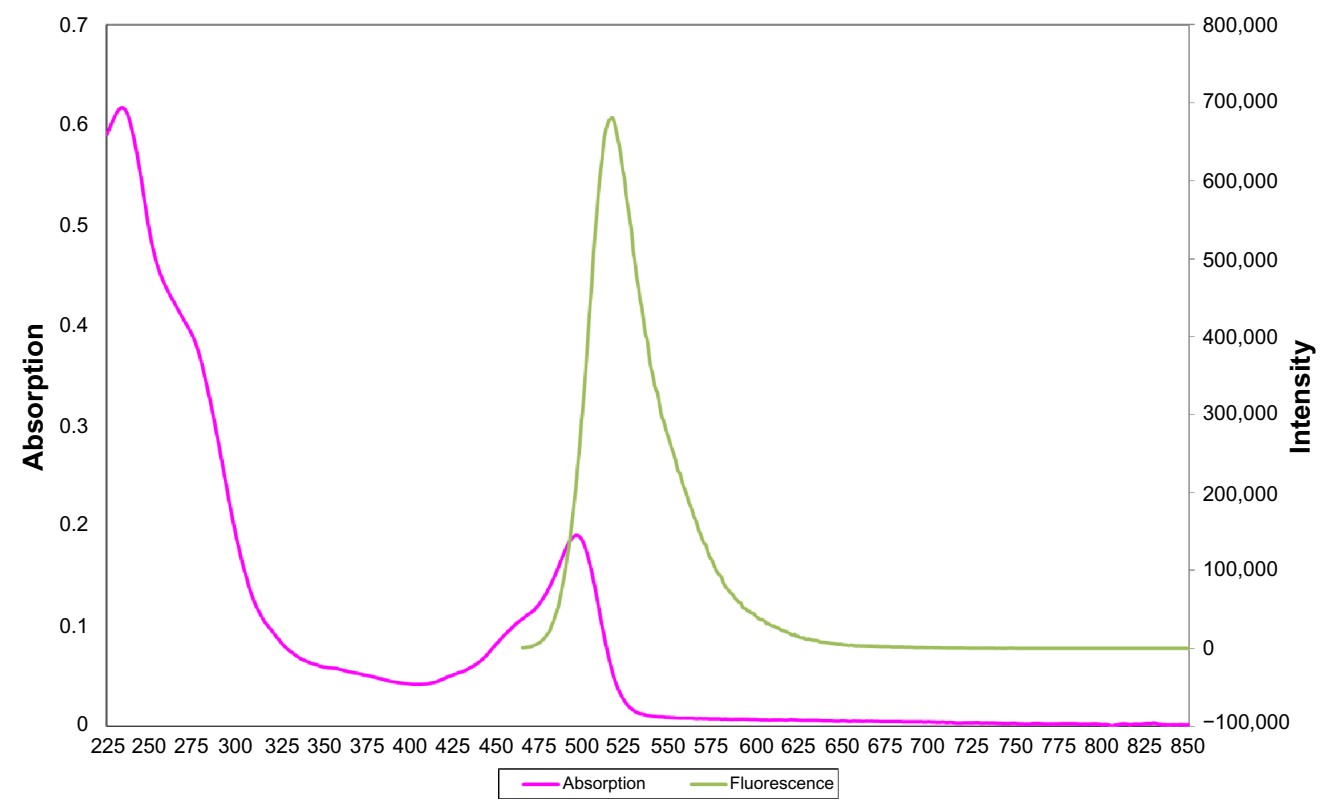

Figure S5 Absorption and fluorescence spectra of silica nanoparticles.

of $95 \%-98 \%$ of NPs in solution. Table S2 summarizes the characteristics of the NPs.

$\mathrm{SiO}_{2}$-FITC NPs were prepared as described previously. ${ }^{2}$ The FITC was covalently bound to the $\mathrm{SiO}_{2}$ core and an $\mathrm{SiO}_{2}$ shell was then produced with the addition of tetraethoxysilane. This shell prevented the influence of the FITC dye on the charge of the NP cores. Successful synthesis of the fluorescent $\mathrm{SiO}_{2} \mathrm{NPs}\left(\mathrm{SiO}_{2}\right.$-FITC) was confirmed by transmission electron microscopy, which showed spherical NPs with no aggregates, agglomerates, or secondary nucleation.

\section{Table S2}

\begin{tabular}{|c|c|c|c|c|}
\hline & $\begin{array}{l}\mathrm{SiO}_{2} \\
\text { plain }\end{array}$ & $\mathrm{SiO}_{2}$-PEG & $\mathrm{SiO}-\mathrm{NH}_{2}$ & $\mathrm{SiO}_{2}-\mathrm{P}$ \\
\hline $\begin{array}{l}\text { Primary particle size } \\
\text { (transmission electron } \\
\text { microscopy) }\end{array}$ & $15 \mathrm{~nm}$ & $15 \mathrm{~nm}$ & $15 \mathrm{~nm}$ & $15 \mathrm{~nm}$ \\
\hline Surface charge & & & & \\
\hline Isoelectric point & $<\mathrm{I}$ & 4 & 7.2 & $<\mathrm{I}$ \\
\hline $\begin{array}{l}\text { C-pot at pH } 7 \\
\text { Dispersability in water } \\
\text { (analytical } \\
\text { ultracentrifugation) }\end{array}$ & $-38 m V$ & $-26 m V$ & $0 \mathrm{mV}$ & $-43 \mathrm{mV}$ \\
\hline D50 & $19 \mathrm{~nm}$ & $21 \mathrm{~nm}$ & $20 \mathrm{~nm}$ & $20 \mathrm{~nm}$ \\
\hline $\begin{array}{l}\text { Av. Agglom. } \\
\text { Number (AAN) }\end{array}$ & I & I & I & I \\
\hline Dispersability in DMEM/ & & & & \\
\hline FCS & & & & \\
\hline D50 & $420 \mathrm{~nm}$ & $3,200 \mathrm{~nm}$ & $\mathrm{I}, 350 \mathrm{~nm}$ & $30 \mathrm{~nm}$ \\
\hline AAN & 28 & 213 & 90 & 2 \\
\hline
\end{tabular}

The size of the particles was determined by transmission electron microscopy and dynamic light scattering (Figure S4A: plain $\mathrm{SiO}_{2}$; $\mathrm{B}: \mathrm{SiO}_{2}$-FITC). The surface charge was measured by electrophoretic mobility with $\mathrm{pH}$ titration. The results showed no significant difference between the plain $\mathrm{SiO}_{2}$ and the fluorescent $\mathrm{SiO}_{2} \mathrm{NPs}$. The fluorescent properties were confirmed by fluorescence spectroscopy (Figure S5). Figure S5 shows the absorption and the emission spectra of the $\mathrm{SiO}_{2}$ particles excited at $460 \mathrm{~nm}$.

\section{References}

1. Wohlleben W. Validity range of centrifuges for the regulation of nanomaterials: from classification to as-tested coronas. J Nanopart Res. 2012;14:1300.

2. Herz E, Ow H, Bonner D, Burns A, Wiesner U. Dye structure-optical property correlations in near-infrared fluorescent core-shell silica nanoparticles. J Mater Chem. 2009;19:6341-6347. 


\section{Publish your work in this journal}

The International Journal of Nanomedicine is an international, peerreviewed journal focusing on the application of nanotechnology in diagnostics, therapeutics, and drug delivery systems throughout the biomedical field. This journal is indexed on PubMed Central, MedLine, CAS, SciSearch $\AA$, Current Contents ${ }^{\circledR} /$ Clinical Medicine,

Journal Citation Reports/Science Edition, EMBase, Scopus and the Elsevier Bibliographic databases. The manuscript management system is completely online and includes a very quick and fair peer-review system, which is all easy to use. Visit http://www.dovepress.com/ testimonials.php to read real quotes from published authors.

Submit your manuscript here: http://www.dovepress.com/international-journal-of-nanomedicine-journal 